\title{
Chapter 2 \\ Live-Attenuated Bacterial Vectors \\ for Delivery of Mucosal Vaccines, DNA \\ Vaccines, and Cancer Immunotherapy
}

\author{
Sudeep Kumar
}

\section{Contents}

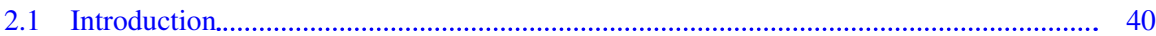

2.2 Desired Features of Live-Attenuated Bacterial Vectors.......................................................... 44

2.2.1 Attenuation.................................................................................................. 44

2.2.2 Plasmid Maintenance............................................................................................... 46

2.3 Immune Mechanisms of Vaccines Delivered by Live-Attenuated Bacterial Vectors......... 47

2.4 Delivery of DNA Vaccines by Live-Attenuated Bacterial Vectors....................................... 50

2.5 Immunotherapy Against Cancer Using Live-Attenuated Bacterial Vectors......................... 52

2.6 Novel Technologies for Tailored and Enhanced Immune Response..................................... 53

2.6.1 Control of Gene Expression: Use of Plasmid Copy Number

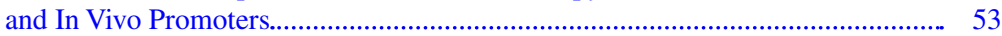

2.6.2 Acid Resistance.......................................................................................... 54

2.6.3 Detoxification of Lipopolysaccharide..................................................................... 54

2.6.4 Optimization of Virulence: Control of Safety and Immunogenicity........................ 55

2.6.5 Cytosolic Delivery of Antigen............................................................................. 55

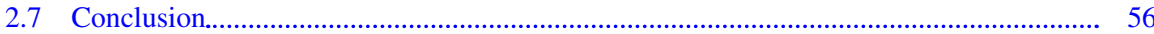

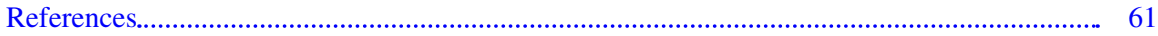

\begin{abstract}
Vaccines save millions of lives each year from various life-threatening infectious diseases, and there are more than 20 vaccines currently licensed for human use worldwide. Moreover, in recent decades immunotherapy has become the mainstream therapy, which highlights the tremendous potential of immune response mediators, including vaccines for prevention and treatment of various forms of cancer. However, despite the tremendous advances in microbiology and immunology, there are several vaccine preventable diseases which still lack effective vaccines. Classically, weakened forms (attenuated) of pathogenic microbes were used as vaccines. Although the attenuated microbes induce effective immune response, a significant risk of reversion to pathogenic forms remains. While in the twenty-first
\end{abstract}

\footnotetext{
S. Kumar $(\square)$

Department of Immunology and Microbial Diseases, Albany Medical Center,

Albany, NY, USA

e-mail: kumars@mail.amc.edu
} 
century, with the advent of genetic engineering, microbes can be tailored with desired properties.

In this review, I have focused on the use of genetically modified bacteria for the delivery of vaccine antigens. More specifically, the live-attenuated bacteria, derived from pathogenic bacteria, possess many features that make them highly suitable vectors for the delivery of vaccine antigens. Bacteria can theoretically express any heterologous gene or can deliver mammalian expression vectors harboring vaccine antigens (DNA vaccines). These properties of live-attenuated microbes are being harnessed to make vaccines against several infectious and noninfectious diseases. In this regard, I have described the desired features of live-attenuated bacterial vectors and the mechanisms of immune responses manifested by live-attenuated bacterial vectors. Interestingly anaerobic bacteria are naturally attracted to tumors, which make them suitable vehicles to deliver tumor-associated antigens thus I have discussed important studies investigating the role of bacterial vectors in immunotherapy. Finally, I have provided important discussion on novel approaches for improvement and tailoring of live-attenuated bacterial vectors for the generation of desired immune responses.

\subsection{Introduction}

Vaccines provide protection against numerous life-threatening infectious diseases, by activating the adaptive immunity against specific pathogen-derived antigens. Since the introduction of active immunization, several vaccines have been licensed for human use. These include some subunit vaccines, which are preferred for their superior safety profile. However, their success is limited by their poor immunogenicity, as multiple booster immunizations and adjuvants are required to achieve an adequate level of protective immunity. Moreover, a subunit vaccine is only applicable for pathogens where a well-defined protective antigen has been discovered. Subunit vaccines are also limited in their ability to induce cell-mediated immunity. In contrast, the live-attenuated/live-inactivated vaccines exhibit superior immunogenicity and induce humoral as well as cell-mediated immunity. Although attenuated viruses and bacteria are both utilized as vaccine vectors, this review will focus only on attenuated bacterial vaccine vectors. Bacteria harbor natural adjuvants in the form of pathogen-associated molecular patterns (PAMPs) (Fig. 2.1). PAMPs, which are recognized by components of the innate immune system including Tolllike receptors (TLRs), facilitate the release of pro-inflammatory mediators and recruitment of antigen-presenting cells (Fig. 2.2). Furthermore, even after attenuation, a limited degree of proliferation and dissemination capacity is retained in the attenuated pathogens. Overall, these factors contribute to the superior immunogenicity of live-attenuated bacteria, which consequently elicit a robust and durable immunity against the cognate antigens.

With the advent of molecular biology and genetics, it is feasible to effectively excise or insert desired genes into bacteria. Bacterial vectors can be engineered to 


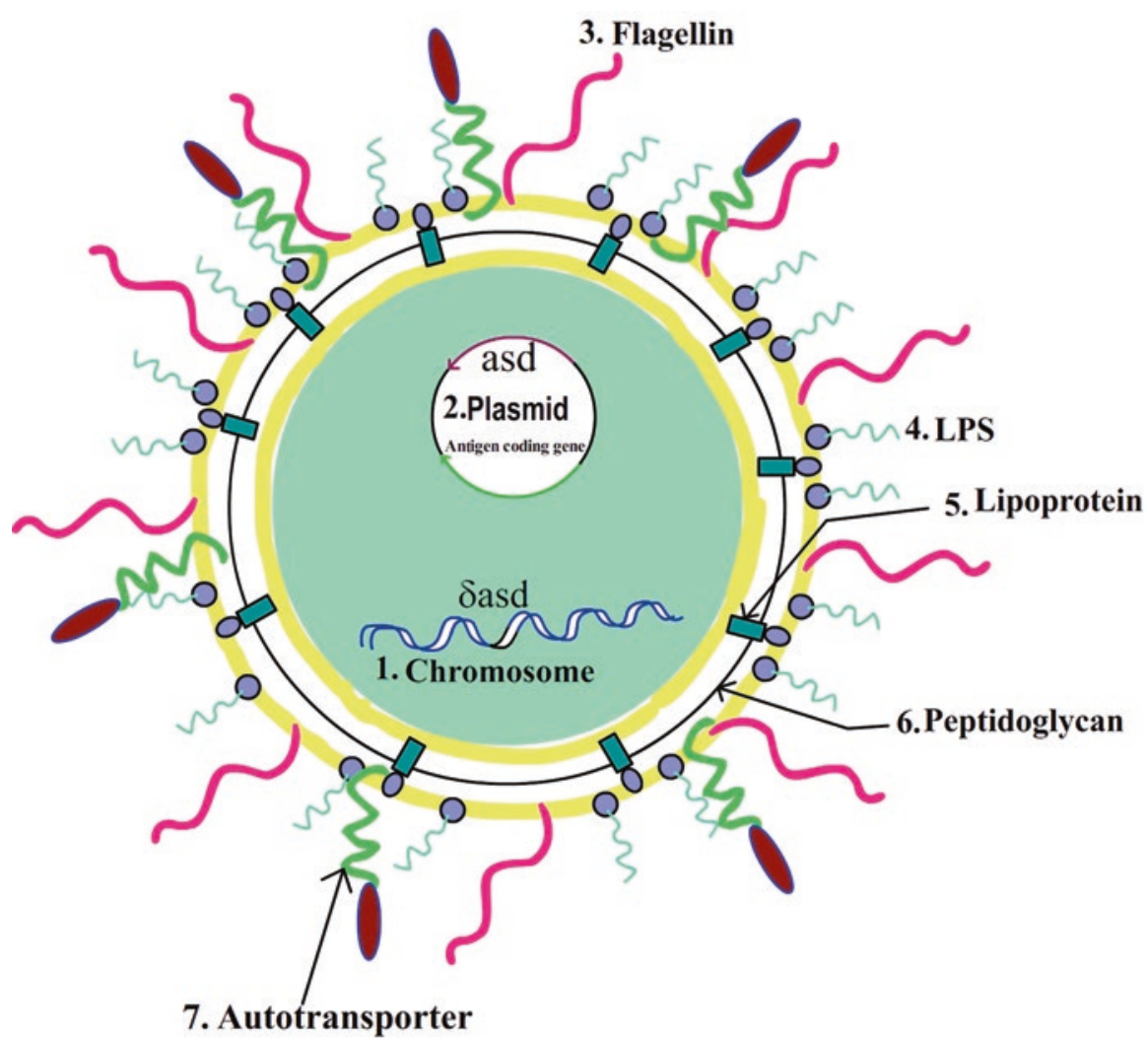

Fig. 2.1 Essential components of live-attenuated bacterial vectors: To construct live-attenuated bacterial vectors, the pathogenicity of bacteria is attenuated by creating mutations in various virulence genes (1). The asd mutation in the chromosome (1) is complemented with a functional copy of asd gene, inserted into the plasmid (2); this feature ensures antibiotic-free maintenance of plasmids. The plasmid (2) also carries genes encoding antigenic proteins. Various pathogen-associated molecular patterns including flagellin (3), lipopolysaccharide (4), lipoprotein (5), and peptidoglycan $(6)$ facilitate the interaction with and signal the activation of antigen-presenting cells, while the additional appendages like autotransporters (7) facilitate surface display of antigens

express and deliver heterologous proteins, such as antigens or therapeutic proteins, in mammalian hosts. Moreover, by genetic manipulation, bacterial vectors can be engineered with properties including reduced virulence, high immunogenicity, properties which are desirable in a vaccine vector. Thus far, a variety of liveattenuated bacterial vectors including Mycobacterium bovis strain Bacillus Calmette-Guérin (BCG), Salmonella spp., Listeria monocytogenes (Lm), Vibrio cholerae, Escherichia coli, and Shigella spp. have been utilized for the delivery of heterologous proteins into mammalian hosts as vaccine antigens or therapeutic proteins. Such bacteria are called, live-attenuated bacterial vectors (LABVs).

Vaccines elicit distinct immune responses depending on the route of immunization. Mucosal immunization induces strong systemic as well as mucosal immune 


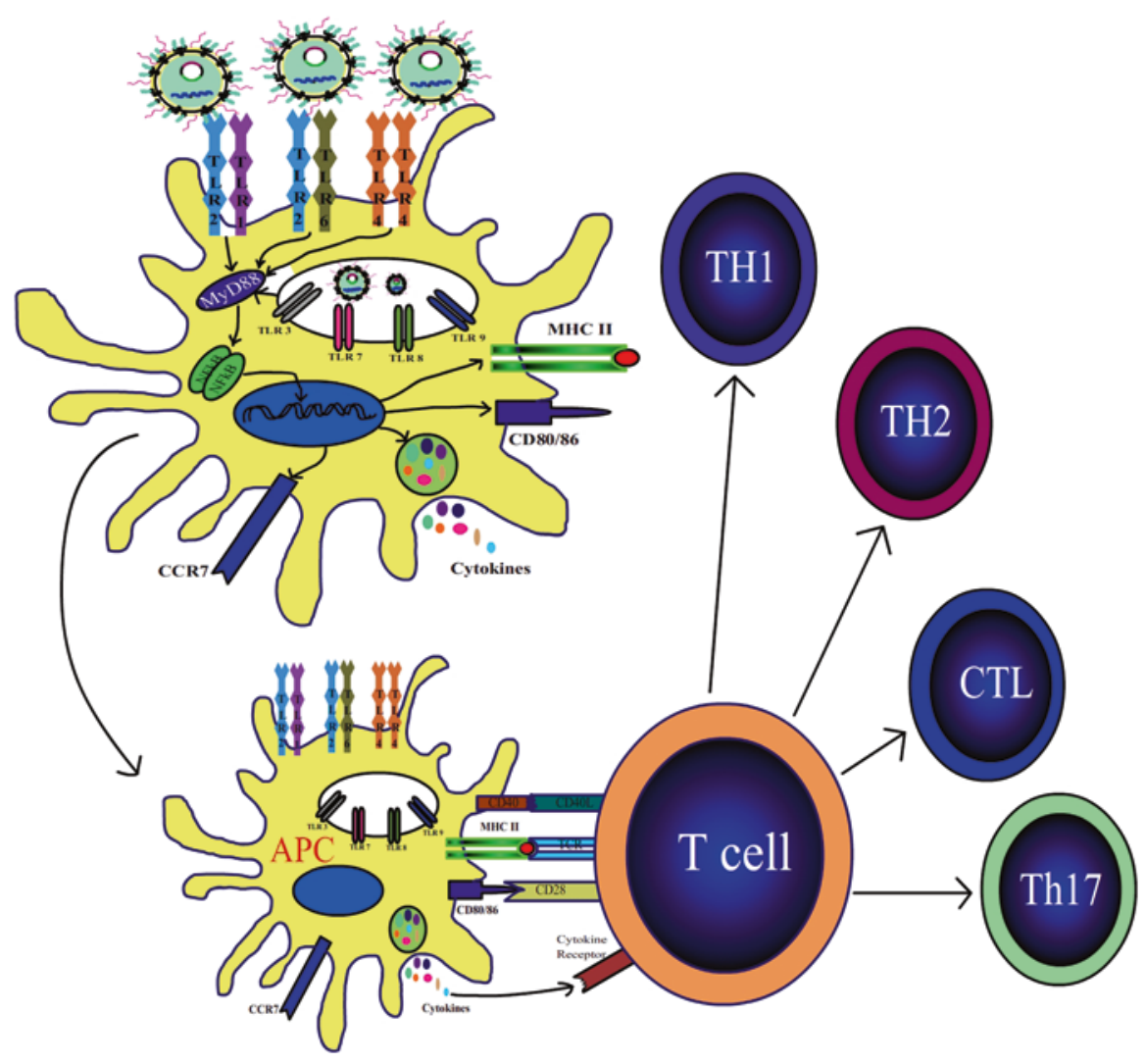

Fig. 2.2 Activation of antigen-presenting cells by live-attenuated bacterial vectors leads to adaptive immune response: Various pathogen-associated molecular patterns present in the liveattenuated bacterial vectors interact with Toll-like receptors expressed on the surface or in endosomal membranes. The signaling initiated by this interaction leads to the activation of antigenpresenting cells. Activated antigen-presenting cells express costimulatory molecules CD80, CD86, and CD40 as well as enhance expression of MHC-II. Costimulatory molecules are required to deliver the essential second signal for T-cell activation, while the first signal is received via TCRMHC-peptide interaction. Importantly, CCR7 expressed by activated APCs help migration to draining lymph node. Moreover, the type of cytokines directs the fate of T-cell polarization to Th1, $\mathrm{Th} 2$, or TH17. Cytosolic delivery of antigens gives rise to CTL response

response, whereas parenteral immunization induces potent systemic but a poor mucosal immune response. Since birth, mucosal surfaces of the human body are constantly challenged with agents of the external environment that are either completely harmless (food ingredients and nonpathogenic microbes) or pathogenic (pathogenic microbes). Thus, in order to restrict pathogenic insults at mucosal surfaces, mucosa-associated lymphoid tissues (MALT) are organized. In fact, MALT constitutes the largest immune system of the human body. The oral route is the most favored route for mucosal immunization over other mucosal routes including nasal, 
vaginal, and rectal. Upon oral administration, antigens travel through the gastrointestinal tract and reach the mucosal inductive sites called Peyer's patches. Peyer's patches are lined with specialized epithelial cells called $\mathbf{M}$ cells which serve as a point of entry into the lamina propria. In the lamina propria, dendritic cells take up the antigens and migrate to the draining lymph nodes where they present the antigens to T cells. A specialized feature of dendritic cells from Peyer's patches and mesenteric lymph nodes is that they induce gut-homing receptors $\alpha 4 / \beta 7$ and CCR 9 on $\mathrm{T}$ and $\mathrm{B}$ cells. This feature is not found in the dendritic cells from cervical lymph nodes and spleen. Thereby, $\mathrm{T}$ and $\mathrm{B}$ cells primed at the mucosal sites are destined to migrate to mucosal tissues (Pasetti et al. 2011) (Fig. 2.3). Live-attenuated microbes exhibit superior ability to deliver vaccine antigens to the mucosal immune system, as many of them are derived from natural mucosal pathogens, including Salmonella spp., Lm, E. coli, V. cholerae, and Shigella spp.

This review explores the current knowledge about the LABV application in the delivery of vaccine antigens (to the mucosal immune system), DNA vaccine, and immunotherapy. Mechanism of immune responses elicited by LABV-based vaccines, the recent advances, and future perspectives have been discussed.
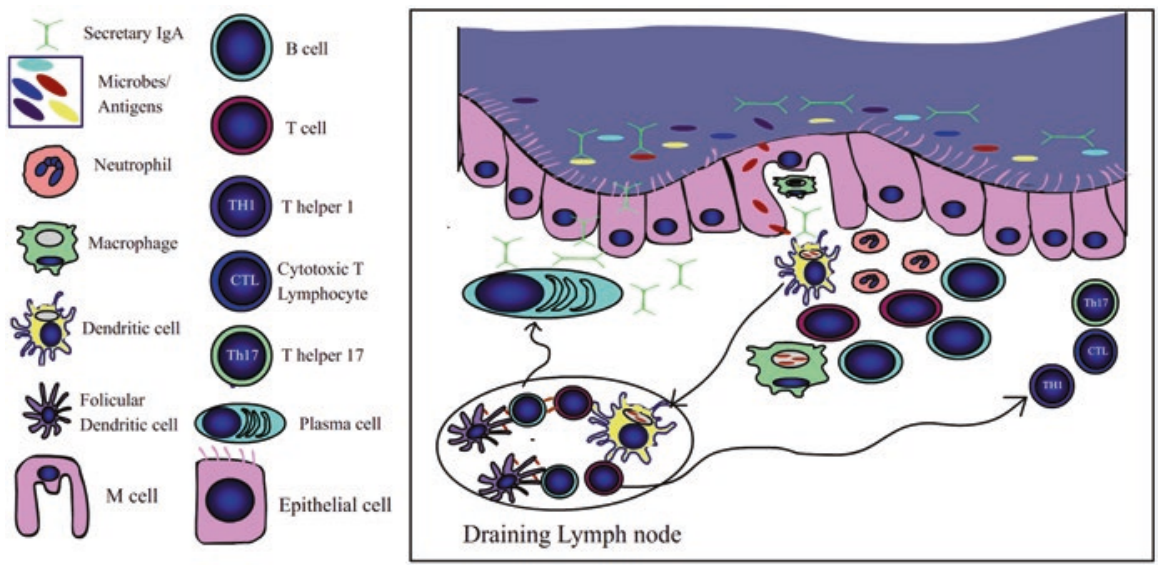

Fig. 2.3 Mucosal immune response elicited by live-attenuated bacterial vectors: Mucosal inductive sites including gut-associated lymphoid tissues and nasal-associated lymphoid tissues facilitate sampling of antigens through $\mathrm{M}$ cells. $\mathrm{M}$ cells allow the passage of bacteria through the mucosal epithelium, where they are taken up by antigen-presenting cells including DCs and macrophages. APCs undergo activation upon interaction with live-attenuated bacterial vectors, and the associated antigens are presented to T cells in the lymphoid follicles or the draining lymph nodes. Activated $\mathrm{T}$ cells help B cells differentiate into IgA-producing plasma cells. The secreted IgA provide effective protection against mucosal pathogens. The $\mathrm{T}$ and $\mathrm{B}$ cells primed at mucosal sites migrate back to mucosal sites where they perform their effector functions 


\subsection{Desired Features of Live-Attenuated Bacterial Vectors}

Nonpathogenic commensals including the lactic acid bacteria and Bacillus subtilis as well as the attenuated versions of the pathogenic bacteria including Salmonella spp., E. coli, Shigella spp., Lm, and V. cholerae have been utilized as LABVs. While the commensal microbes are generally regarded as safe or food grade, the virulence of the pathogenic microbes needs to be significantly attenuated before they can be considered safe to deliver vaccine antigens into humans (Fig. 2.1).

Generally, plasmids are employed for the expression of heterologous antigens in LABVs. Plasmids can be easily manipulated in E. coli (a universal tool for genetic engineering) and subsequently introduced into the desired bacterial strains. Shuttle vectors (plasmids) carry genetic elements for replication in E. coli and promoter elements for gene expression in other bacterial or mammalian cells. Thus, mammalian expression vectors can be first manipulated and propagated in E. coli and then delivered via LABVs to mammalian cells, where the desired antigens are expressed (Fig. 2.1).

\subsubsection{Attenuation}

In early days, attenuation of the pathogenic microbes was achieved by in vitro cultivation for several generations, followed by the evaluation of virulence in successive generations. The classic example is BCG, where Albert Calmette and Camille Guerin, by culturing a virulent strain of $M$. bovis for more than 230 serial passages in vitro (between 1908 and 1921), generated the attenuated strain BCG. BCG is still the only vaccine available for prevention against tuberculosis. Subsequent genetic analysis revealed that BCG lack multiple virulence factors associated with $M$. bovis (Zheng et al. 2015). Similarly, the search for vaccines against typhoid fever led to the generation of attenuated live vaccine strains of Salmonella. Salmonella enterica serotype Typhi (ST) strain Ty21a (ST-Ty21a) was generated by chemical mutagenesis of wild-type ST strain Ty2. The ST-Ty21a is considerably attenuated which is now licensed for humans use as an oral vaccine (Wang et al. 2001). However, the strain exhibits low immunogenicity, as 3-4 doses are required to achieve adequate levels of protection. With the advances in microbial genetics and genetic engineering techniques, it has now become routine to identify and inactivate virulence genes. Interestingly, various auxotrophic mutant Salmonella strains, which lack the ability to synthesize aromatic amino acids, were found to be avirulent (Hoiseth and Stocker 1981). It is known that in Salmonella, the gene products of aroA, aroC, and aroD are required for the biosynthesis of aromatic amino acids, as well as several essential vitamins. Hoiseth and Stocker note that these factors are not found in mammalian hosts in sufficient amount; thus Salmonella aroA mutants cannot proliferate in mammalian hosts (Hoiseth and Stocker 1981). Harnessing this knowledge, various Salmonella enterica serovar Typhi (ST) or Typhimurium (STm) have been created, 
with mutations in aroA (Dalla Pozza et al. 1998; Roberts et al. 2000; Arnold et al. 2004), aroC (Khan et al. 2003; Capozzo et al. 2004), aroD (Capozzo et al. 2004; Sevil Domènech et al. 2008), or aroAD (Strugnell et al. 1992; Roberts et al. 2000). Notably, the ST strain CVD908 which carries $\operatorname{aroC}$ and $\operatorname{aroD}$ mutations exhibits residual virulence in humans (Wang et al. 2001), while other investigators have also targeted genes in nucleotide biosynthesis pathways for creating attenuated Salmonella. Wang et al. engineered a Salmonella strain with a mutation in guaBA operon, which interferes in the guanine nucleotide biosynthesis. The resultant strain, called CVD 915, exhibits safety profile comparable to that of the typhoid vaccine strain ST-Ty21a. Importantly, ST-Ty21a, CVD-908-htrA (harboring mutations at aro $C$, $a r o D$, and $h t r A$ ), and CVD 915 all exhibit a high level of immunogenicity (Wang et al. 2001). Not surprisingly, ST strains with guaBA mutations have been widely utilized as LABV (Pasetti et al. 1999, 2000; Wang et al. 2001). Another approach of attenuation of Salmonella is to introduce mutations in cya (adenylate cyclase) and crp (cyclic AMP) receptor genes. These proteins are transcriptional regulators of many important genes. Although cAMP is found in mammalian cells, their concentrations in gastrointestinal tissues are below the requirement of Salmonella. Thus cya and crp mutants show reduced virulence (Tacket et al. 1992; Chen and Schifferli 2003; Wyszyńska et al. 2004; Ferreira Oliveira et al. 2012). Mutations in the two-component regulatory system PhoP/PhoQ, which controls more than 40 virulence genes involved in resistance to antimicrobial peptides, nutrient scavenging, and lipid A modifications, significantly decrease Salmonella virulence (Raupach and Kaufmann 2001). Salmonella strains with PhoP/PhoQ mutations have been used in a number of studies as LABV (Angelakopoulos and Hohmann 2000; Kotton et al. 2006; Galen et al. 2009; Wang et al. 2013). RpoS is an alternate sigma factor that regulates resistance under stress induced during gastrointestinal infection such as $\mathrm{pH}$, nutrient starvation, change in osmolarity, and temperature. ST-Ty21a contains multiple mutations including $r p o S$ (Wang et al. 2001). SsaV is a component of Salmonella type III secretion system, which is required for secretion of SPI-2 genes (essential for growth in macrophages). The ST strain ZH9 which contains $\operatorname{aroC}$ and ssaV mutations is highly attenuated and immunogenic in humans (Hindle et al. 2002). Tacket et al. generated mutations in htrA gene, which encodes a heat shock protein. The resultant strain was avirulent because of reduced ability to survive and replicate in host tissues (Tacket et al. 2000). HtrA mutant Salmonella strains have been used in multiple studies as LABVs (Galen et al. 1999; Roberts et al. 2000; Pasetti et al. 2002; Capozzo et al. 2004; Fraillery et al. 2007).

Similarly, for attenuation of $\mathrm{Lm}$, multiple virulence factors have been targeted. ActA which encodes for a surface protein required for actin polymerization in host cells and helps in intracellular migration has been a prominent target for Lm attenuation. Together with the mutation in internalin B (inlB), the actA mutation renders Lm unable to infect hepatocytes; thus these strains are highly attenuated (Brockstedt et al. 2004). Phospholipase-C B (PlcB) is required for efficient escape from phagosomal vacuoles. $P l c B$ mutants are thus attenuated due to defect in escape from secondary vacuoles (Peters et al. 2003; Starks et al. 2004; Stevens et al. 2004; Johnson et al. 2011; Jia et al. 2012; Liang et al. 2014). Cell wall biosynthesis genes 
specifically dal (alanine racemase) and dat (D-amino acid aminotransferase) have been mutated in several attenuated $L m$ vaccine vectors (Friedman et al. 2000; Verch et al. 2004; Jiang et al. 2007; Im et al. 2013). The double mutant of $L m$ requires $\mathrm{D}$-alanine for cell wall biosynthesis and is highly attenuated. Recently McLaughlin et al. demonstrated that deletion of $L m$ fur-regulated virulence factor A ( frvA) results in attenuation in murine models of infection, due to the inability of iron homeostasis (McLaughlin et al. 2013).

Attenuated strains of Shigella are also being used as LABV. Noriega et al. (Noriega et al. 1996) generated guaBA mutant of Shigella CVD1204, which is highly attenuated in animals and is widely used as LABV. Other approaches of mutations include SC602, with deletions on icsA (mediate intra- and intercellular spread) and iucA (aerobactin); this strain is highly attenuated and immunogenic (Ranallo et al. 2005).

\subsubsection{Plasmid Maintenance}

Introduction of heterologous genes into bacterial vectors is facilitated by plasmids. Plasmids are extrachromosomal circular DNA, which are introduced into bacteria by a process called transformation. Generally, bacteria maintain the plasmids utilizing antibiotic resistance mechanism. During in vitro growth, antibiotic selection pressure ensures stable plasmid maintenance; however, in the in vivo conditions, the lack of antibiotic selection pressure plasmid-less bacteria outgrows plasmid-bearing bacteria. Moreover, the use of antibiotic markers are also discouraged, due to the risk of horizontal gene transfer to other microbes with pathogenic potential (Lin et al. 2015; Mignon et al. 2015). Novel antibiotic-free approaches of plasmid maintenance have been devised to mitigate these concerns. One such approach, known as the balanced lethal system, utilizes mutation in an essential gene in the bacterial chromosome, while the plasmid carries the functional copy of the same gene, thereby ensuring its maintenance by the bacteria (Fig. 2.1). Galen et al. generated a balanced lethal system for STm based on mutation in asd gene. Asd encodes aspartate semialdehyde dehydrogenase, an enzyme required in the biosynthesis pathway of DAP (diaminopimelic acid), which is an essential component of bacterial cell wall. DAP is needed for growth and maintenance of asd mutants. A copy of asd gene is inserted into the plasmid; thus asd-deficient bacteria are forced to maintain the plasmid in order to survive in DAP-deprived conditions, such as in the mammalian tissues. The resultant Salmonella typhimurium (STm)-based balanced lethal system exhibits high degree of plasmid stability. This system also exhibits stable expression of the associated heterologous genes (Galán et al. 1990). Balanced lethal system has been most widely used in various LABVs including $S T$ (Tacket et al. 1997), STm (Kang et al. 2002), and S. flexneri (Zheng et al. 2005). Similarly, thymidine auxotrophy has also been utilized in ST (Bumann et al. 2010), STm (Mignon et al. 2015), and lactic acid bacteria (Bermúdez-Humarán et al. 2011) for balanced lethal system approach of plasmid maintenance. Glutamine auxotroph V. cholerae complemented with $g \ln A$ gene is another example of the balanced lethal system utilized for antibiotic-free plasmid maintenance (Ryan et al. 2000). 


\subsection{Immune Mechanisms of Vaccines Delivered by Live- Attenuated Bacterial Vectors}

Various mucosal pathogens and nonpathogenic food grade microbes have been extensively utilized for LABV development. Salmonella infect via orogastric route and enter the intestinal lamina propria by transcytosis via $\mathrm{M}$ cells, which are present in the mucosal inductive sites (Peyer's patches). In the lamina propria, Salmonella is taken up by various phagocytes including neutrophils, macrophages, and dendritic cells. The infected phagocytes then carry Salmonella to various organs including the liver and spleen via blood or to the mesenteric lymph nodes via lymph. The virulence factors, clustered in Salmonella pathogenicity islands (SPI-1 and SPI-2), facilitate invasion, survival, and proliferation in the intracellular spaces of macrophages (Pham and McSorley 2015). Salmonella possess a variety of pathogen-associated molecular patterns (PAMPs) including lipoprotein, lipopolysaccharide (LPS), flagellin (FliC), and $\mathrm{CpG}$. These PAMPs are recognized by host pattern recognition receptors (PRRs) including TLR 2(1/6) (lipoproteins), TLR4 (LPS), TLR 5 (FliC), or TLR9 (CpG). Activation of these PRRs leads to the expression and secretion of cytokines such as TNF $\alpha$, IL1 $\beta$, IL6, IL8, IL12, IL-18, and IL-23 (Broz et al. 2012). These pro-inflammatory factors recruit neutrophils, macrophages, and dendritic cells. On the other hand, upon interaction with Salmonella LPS and flagellin, dendritic cells increase the expression of CCR7, CD80, CD86, and CD40. These mature dendritic cells with enhanced capability to process and present antigens can migrate to T-cell areas and initiate adaptive immune responses to cognate antigens. Studies suggest that Salmonella induces humoral as well as $\mathrm{CD}^{+}{ }_{-}, \mathrm{CD}^{+}{ }^{-}$, and Th17-dependent cellmediated immune responses (Pham and McSorley 2015). Heterologous antigens carried by Salmonella elicit serum IgG (Frey et al. 2013), mucosal IgA (Allen et al. 2000; Ferreira Oliveira et al. 2012; Pei et al. 2015; Lalsiamthara and Lee 2017), $\mathrm{CD}^{+}$(Ramirez et al. 2009; Ashraf et al. 2011), and CD8 ${ }^{+}$T cells (Luria-Perez et al. 2007; Sevil Domènech et al. 2008; Berchtold et al. 2009). Due to the versatile immune response elicited by Salmonella, ST- and STm-based LABVs have been utilized to develop vaccines against numerous viral, bacterial (extracellular and intracellular), and parasitic pathogens. Importantly, it is well known that neutralizing antibodies and CTL responses confer adequate protection against viral pathogens; thus $S T$ - and $S T m$-based LABVs are capable of eliciting adequate antiviral immune responses. Antigens from viral pathogens including H1N1, H5N1, HIV, and SARS virus, when delivered by $S T$ or $S T m$, elicit antigen-specific antibody response (Karpenko et al. 2004; Luo et al. 2007; Pei et al. 2015; Hajam and Lee 2017). On the other hand, CTL response is generated against dengue virus (NS3) and HIV antigens (Karpenko et al. 2004; Luria-Perez et al. 2007). LABVs based on ST and STm elicit serum IgG, mucosal IgA, CD4 ${ }^{+} \mathrm{T}$-cell, and $\mathrm{CD}^{+} \mathrm{T}$-cell responses against a variety of bacterial pathogens including B. anthracis (Galen et al. 2010), B. pertussis (Dalla Pozza et al. 1998), E. coli (Ferreira Oliveira et al. 2012), Helicobacter pylori (Angelakopoulos and Hohmann 2000), L. monocytogenes (Igwe et al. 2002), Pseudomonas aeruginosa (Bumann et al. 2010), Streptococcus pneumoniae (Shi et al. 2010), and Yersinia pestis (Branger et al. 2010). While antigen-specific Th1 
responses are generated against some parasitic pathogens including Leishmania mexicana (González et al. 1998), Schistosoma japonicum (Chen et al. 2011), and Taenia solium (Ding et al. 2013), mucosal IgG and IgA are generated against Giardia lamblia (Abdul-Wahid and Faubert 2007) and Cryptosporidium parvum (Benitez et al. 2009) by $S T$ - and $S T m$-based LABVs carrying related antigens.

Besides Salmonella, Listeria is the most extensively studied bacteria as LABV. Similar to Salmonella, Listeria infection begins with orogastric infection. $\mathrm{Lm}$ moves across gastrointestinal epithelial barrier by first attaching to and invading epithelial cells. Adhesion and internalization require $\mathrm{Lm}$ protein Ami and internalin A (inlA), respectively. Once in the lamina propria $L m$ rapidly spreads systemically. Lm primarily targets liver with the help of fibronectin binding protein (FbpA). FbpA recognizes fibronectin on the surface of hepatocytes, and at this point another molecule, called internalin (inlB), facilitates $\mathrm{Lm}$ internalization. On the other hand, phagocytes specifically macrophages and monocytes recognize lipoteichoic acid via scavenger receptors. After the phagocytosis $L m$ escapes phagocytic vesicles by synergistic activities of listeriolysin O (LLO) and two phospholipase C (PlcA and $\mathrm{PlcB}$ ). Another virulence factor is ActA, which has actin polymerization activity and helps $\mathrm{Lm}$ migrate from cell to cell (Liang et al. 2014). Lm expresses various TLR agonists including peptidoglycan, flagellin, and bacterial DNA, which induces pro-inflammatory cytokines including TNF $\alpha, \operatorname{IFN} \gamma, \operatorname{IL} 1 \beta$, and IL12. Lm-induced cell death results in secretion of IL6, which helps in recruitment of neutrophils. IL12 helps in induction of IFN $\gamma$ by NK cells and $\mathrm{CD} 8^{+} \mathrm{T}$ cells. $\mathrm{Lm}$ can also induce type-I IFNs (IFN $\alpha$ and IFN $\beta$ ), which is desirable as antiviral immunity. Evidences suggest that $\mathrm{Lm}$ induces both $\mathrm{CD}^{+}$and $\mathrm{CD} 8^{+} \mathrm{T}$-cell-mediated immune response (Zenewicz and Shen 2007; Liang et al. 2014). Lm-carrying viral antigens such as HIV/SIV-gag (Frankel et al. 1995; Friedman et al. 2000; Im et al. 2013), HPV-E7 (Jia et al. 2012), and LCMV-NP118-126 (Tvinnereim et al. 2002) induces CTL immune response. $\mathrm{Lm}$-based LABV also induces neutralizing antibody against HIV-gp160 (Lakhashe et al. 2011). However, there are limited reports on Lm as LABV against bacterial and parasitic pathogens. In one study, Lm-carrying Coxiella burnetii antigen T4SS (epitopes) induced $\mathrm{CD}^{+} \mathrm{T}$-cell immune response (Xiong et al. 2017). In another study Lm-carrying Francisella tularensis antigen IglC induced IFN $\gamma$ producing $\mathrm{CD}^{+}$and $\mathrm{CD} 8^{+} \mathrm{T}$-cell-mediated immune response.

BCG, an attenuated M. bovis, has also exhibited potential as LABV. Following immunization, BCG interacts with phagocytes such as macrophage, dendritic cells, and neutrophils. Various PRRs of macrophages involved in interaction with BCG include CR3, TLR2 (1/6) and TLR-4. However, dendritic cells utilize a different set of phagocytic receptors including CR3, CR4, DC-SIGN (CD209), and DEC 205. Infected dendritic cells upregulate expression of MHC-II and costimulatory markers CD80, CD86, CD40, and CD54 which are involved in activation of adaptive immune response (Moliva et al. 2017). BCG is known to induce humoral as well as T-cell-mediated immune response (Abomoelak et al. 1999). The T-cell responses induced by BCG include polyfunctional $\mathrm{CD}^{+} \mathrm{T}$ cells that secret TNF, IL-2, and IFN $\gamma$ (Moliva et al. 2017). BCG expressing IL12 and two M. tuberculosis (Mtb) antigens (secreting antigen $\mathrm{Ag} 85 \mathrm{~B}$ and culture filtrate antigen CFP10) induce antigen-specific Th1-type immune response including IFN $\gamma$-producing cells and 
$\operatorname{IgG2a}$ (Chen et al. 2017). Antigen-specific humoral immune response is induced by BCG expressing a hepatitis-B surface antigen (Rezende et al. 2005). BCG-induced $\mathrm{CD}^{+} \mathrm{T}$ cells also secrete IFN $\gamma$ (Moliva et al. 2017). In a mouse model, BCG carrying $M t b$ antigen (Ag85B) exhibit antigen-specific Th17 immune response (Hatano et al. 2016). Pertussis toxin subunit $\mathrm{S} 1$ expressed by BCG induces IFN $\gamma$ producing $\mathrm{CD}^{+} \mathrm{T}$ cells which completely protects against lethal Bordetella pertussis challenge (Nascimento et al. 2008). Furthermore, in a mouse model of an intracellular pathogen $\mathrm{Lm}$, BCG expressing $\mathrm{Lm}$ antigen p60 induced $\mathrm{CD} 4^{+}$and $\mathrm{CD} 8^{+} \mathrm{T}-$ celldependent protection (Grode et al. 2002). Studies have demonstrated that BCG induces long-lived mycobacteria-specific memory B cells. Moreover, following BCG immunization, hosts secrete robust $M t b$-specific serum antibodies including $\operatorname{IgG}$ isotypes $\operatorname{IgG1} \operatorname{IgG} 2$, and $\operatorname{IgG} 3$. However, it is not known if specific mucosal IgA is induced by BCG (Moliva et al. 2017).

$S$. flexneri infection occurs through orogastric route. Once in the colon, S. flex$n e r i$ crosses epithelial layer through highly endocytic M cells. S. flexneri then adhere to and infect colonic epithelium through the basolateral surface. Colonic epithelial cells engulf $S$. flexneri by macropinocytosis, and through the activity of IpaB and IpaC, they are released from macropinocytic vacuoles to the cytosol (Mellouk and Enninga 2016). S. flexneri invasion causes activation of innate immune system and release of a variety of cytokines including IL-1, TNF- $\alpha$, IL6, TGF- $\beta$, and IL-8 (Fernandez and Sansonetti 2003; Jennison and Verma 2004). Though Shigella has the capacity of cell-to-cell translocation, its infection is limited to lamina propria of the intestine, and it doesn't migrate to other organs (Maurelli and Sansonetti 1988). In the lamina propria $S$. flexneri is phagocytosed by macrophages and dendritic cells. Infected macrophages undergo apoptosis, which leads to the release of proinflammatory cytokine IL1, IL18, and IFN $\gamma$ (Fernandez and Sansonetti 2003). S flexneri induces both systemic and mucosal antibody response including IgM, IgG, and secretory IgA (Jennison and Verma 2004). S. flexneri $2 a$ with guaBA mutation (CVD 1204) has limited invasiveness, and proliferative capacity. Attenuated S. flexneri expressing ETEC antigens CFA-I, LTB, CS2, CS3, and CS4 induce antigenspecific serum IgG and mucosal IgA (Koprowski et al. 2000; Barry et al. 2003; Strain et al. 2003; Ranallo et al. 2005; Zheng et al. 2005).

Food grade bacteria including $B$. subtilis and Lactobacillus lactis are considered important candidates for LABV, due to their superior safety profile. Upon oral administration, $B$. subtilis spores can safely transit through the stomach, germinate, and proliferate in the upper intestine and finally undergo re-sporulation in the colon (Cutting et al. 2009). Nevertheless, the mechanism of immune response in response to $B$. subtilis delivered antigens is not fully understood. Antigens delivered by $B$. subtilis have been shown to induce humoral as well as Th1-mediated immune response (Cutting et al. 2009). B. subtilis has been used as LABV for various bacterial and parasitic pathogens including pathogenic E. coli, H. pylori, Mtb, Clonorchis sinensis, and S. japonicum. B. subtilis induces systemic IgG (Amuguni and Tzipori 2012; Zhou et al. 2015), mucosal IgA (Amuguni and Tzipori 2012; Zhou et al. 2015), and Th1/Th17 (Sibley et al. 2014; Stasilojc et al. 2015) immune response against cognate antigens. The lactic acid bacteria are among the microbes, which occur physiologically in animal digestive tracts and like other natural microflora 
through their metabolites and interaction with macrophages can stimulate cytokine production. Peptidoglycan of the lactic acid bacteria induces secretion of IL1, IL6, and TNF, by monocytes (Bermúdez-Humarán et al. 2011; Szatraj et al. 2017). Unlike attenuated strains of otherwise pathogenic microbes used as LABV, B. subtilis and L. lactis do not invade through the gut mucosa and serve mainly as protein (antigen) factories, which supply vaccine antigens to gut-associated lymphoid tissue (GALT). Protective antigens of pathogenic viruses H1N1 (HA) and H5N1 (HA) expressed by L. lactis induce mucosal antibodies. L. lactis expressing bacterial antigens Campylobacter jejuni (cjAD) (Kobierecka et al. 2016), Clostridium difficile (TcdA) (Yang et al. 2013), Clostridium perfringens (epsilon toxoid) (Alimolaei et al. 2016), H. pylori (omp22, HpaA, cag12, and UreaseB) (Kim et al. 2006; Gu et al. 2009; Zhang et al. 2016b), and V. cholerae (WZM) (Zamri et al. 2012) also induce mucosal antibodies.

\subsection{Delivery of DNA Vaccines by Live-Attenuated Bacterial Vectors}

In preclinical models, DNA vaccines have proven to confer protective immunity against a variety of infectious agents including HIV, herpes simplex virus (HSV), Plasmodium spp., and Mtb (Schoen et al. 2004). An attractive feature of DNA vaccine is that it can induce humoral as well as cell-mediated immune response. While antibodies alone can protect against many pathogens and toxins, cell-mediated immunity is required for protection against intracellular pathogens and cancer. The DNA vaccines in the form of eukaryotic expression plasmids are delivered either by intramuscular injection of naked DNA, intradermal bombardment using DNA coated on gold particles with help of a gene gun, or electroporation following needle injection. However, most of these methods induce only moderate levels of protection in animal models and fail to show efficacy in clinical trials (Schoen et al. 2004). In recent years many bacterial vectors have been utilized to deliver plasmids into the host cells (Schoen et al. 2004). As many attenuated strains are being developed for delivery of vaccine antigens, similar strains can also be utilized to deliver plasmids as DNA vaccines. Attenuated strains of gut pathogens including ST, STm, or L. monocytogenes are of particular importance, as they colonize and infect mucosal epithelial cells.

As discussed above, Listeria infection begins at gastrointestinal tract, and after invasion through intestinal mucosa, Listeria migrate through blood vessels and lymph to other organs. Listeria can infect a wide array of cell types including intestinal epithelial cells, hepatocytes, dendritic cells, and macrophages. Listeria escape phagocytic vesicles and multiply in cytosol where they release the plasmids. Listeriolysin O helps Listeria lyse and escapes the phagosomal vacuoles (Liang et al. 2014). Miki et al. engineered a self-destructing $L m$-based vaccine delivering a eukaryotic expression plasmid encoding Mtb antigens Ag85a/Ag85b and MPB/ MPT51. The vaccine induced protective immune response against $M t b$ in a mouse model (Miki et al. 2004). 
Salmonella also infects via gastrointestinal tract, and after crossing epithelial barrier through M cells, Salmonella is taken up by macrophages (Pham and McSorley 2015). Salmonella has the capability of surviving and replicating in phagocytic vacuoles (Pham and McSorley 2015). However, through unknown mechanisms, they can release plasmid DNA into the cytosol (Schoen et al. 2004). Salmonella strains expressing listeriolysin $\mathrm{O}$ have been shown to escape the phagosome vesicles to the cytosol, thus making gene transfer by Salmonella more efficient (Schoen et al. 2004). HIV-1 T-cell epitopes in the form of eukaryotic expression plasmid delivered by attenuated STm induced CTL as well as antibody immune response (Karpenko et al. 2004). Another study targeting an S. pneumoniae protective antigen PsaA and PspA delivered by STm induced mucosal IgA against both antigens. Thus immunized mice were protected against nasopharyngeal colonization by S. pneumoniae (Zhang et al. 2011). Pathogenic parasites Trichinella spiralis and Trypanosoma cruzi have also been targeted for STm-mediated DNA vaccination. Yang et al. constructed a DNA vaccine against $T$. spiralis using antigen Ts87 and STm as the delivery vehicle. Mice immunized orally with this vaccine induced antigen-specific mucosal IgA which correlated with protection against $T$. spiralis larval challenge. Salmonella-delivered T. spiralis DNA vaccine induced a Th1-I Th2-type immunity and IL5, IL6, and IL10 cytokines (Yang et al. 2010). In another study, Matos et al. using STm delivered T. cruzi antigens (Tc-52) into mice via the oral route. Immunized mice elicited specific antibodies with higher IgG2a/IgG1 ratio, suggesting a Th1 bias. The vaccinated group also induced strong cell-mediated immunity and mucosal IgA (Matos et al. 2014).

Most bacteria used as DNA delivery vehicles were designed to disintegrate after infecting host cells. If the bacterial DNA vaccine vectors are destroyed in the phagolysosomes, before reaching the cell cytoplasm, it will lead to inefficient delivery of the plasmid. To circumvent this problem various approaches have been devised. One such approach takes advantage of phage lysin to disintegrate $\Delta$ aroA- $L m$ after reaching host cell cytosol. The inclusion of phage lysin significantly improved bactofection (bacteria-mediated delivery of plasmid DNA into mammalian cells) efficiency in phagocytic as well as non-phagocytic cells (Pilgrim et al. 2003). Recently, Kong et al. developed a universal DNA vaccine delivery platform, which includes several modalities for enhanced delivery and immune response to cognate antigens. The attenuated STm includes the capability to escape the phagosomal compartment to the cytosol of the host cells, before phagolysosomal degradation (Kong et al. 2012). SifA proteins direct Salmonella-induced filament formation when Salmonella is contained in the endosomal vacuoles, and the deletion of sifA gene results in the release of Salmonella into the cytosol. Hence, mutation of sifA gene in Salmonella plasmid carriers allowed successful transfer of plasmid DNA into the cytosol of the host cells (Kong et al. 2012). Kong et al. also incorporated elements that guide the plasmid into the nucleus. Transcription factors such as NF- $\mathrm{kB}$ and AP2 bind to plasmids carrying NF- $\mathrm{KB}$ and AP2 binding sequences and transport them to the nucleus where the desired antigens are transcribed (Kong et al. 2012). Salmonella induces apoptosis/pyroptosis in infected cells that diminishes the overall transfection efficiency. Deletion of $t l p A$ and $s s e L$ genes significantly reduces apoptosis in 
host cells (Kong et al. 2012). Moreover, Salmonella degradation is delayed due to the regulated expression of the Salmonella lysis program. This allows a limited number of replication and invasiveness, thereby ensuring optimal delivery of plasmids. An influenza antigen (HA) delivered by this platform induced enhanced HA-specific IgG, which correlated with protection against influenza virus challenge (Kong et al. 2012).

\subsection{Immunotherapy Against Cancer Using Live-Attenuated Bacterial Vectors}

A nineteenth-century physician, William B. Coley, for the first time observed regression of malignant tumor in one of his patients after a bacterial infection. Coley went on to develop the first bacterial therapy against cancer using killed gram-positive bacteria streptococci and a gram-negative bacteria Serratia marcescens. This mixture called "Coley's toxins" when injected into patients suffering from various forms of cancer resulted in partial to complete regression. In cases of soft tissue sarcoma, long-term disease-free survival was achieved in approximately $50 \%$ of the patients. Nevertheless, despite the remarkable success of "Coley's toxins," with the advent of chemotherapy and radiotherapy, this line of investigation was prematurely abandoned (Bickels et al. 2002). However, in recent years this approach is regaining attention. In fact, BCG is currently being used as immunotherapy for bladder cancer and exhibits superiority over epirubicin and IFN $22 \mathrm{~b}$, mitomycin, and epirubicin alone (Fuge et al. 2015). Since the first report of BCG's use in cancer treatment in 1936, preclinical and clinical investigations of BCG have also been reported for other forms of cancer. Mice preimmunized with BCG exhibited slower tumor growth compared to control (Zheng et al. 2015). Morton et al. reported complete regression of tumor lesions in melanoma patients, upon intralesional injection of BCG in 684 out of 754 lesions. Similarly, survival benefits against cancer were also reported in other clinical trials. See Zheng et al. for a detailed review on application of BCG in cancer therapy (Zheng et al. 2015).

Bacteria, specifically anaerobes, exhibit natural tropism toward solid tumors. This phenomenon, although poorly understood, is theorized that certain characteristics of tumor microenvironment facilitate this phenomenon. The deeper pockets of tumors, which are devoid of new blood vessels, are poorly oxygenated and show limited accessibility to chemotherapeutic drugs (Lee 2012; Lin et al. 2015). Forbes et al. demonstrated that STm accumulate at a rate of 2000-fold more compared to other organs including the liver, spleen, lung, heart, and skin (Forbes et al. 2003). Using an in vitro model, Kasinkas and Forbes demonstrated that STm exhibits chemotaxis. Depending on the availability of specific receptors (tsr, tar, and trg), STm were differentially attracted to corresponding chemoattractants expressed in the tumor microenvironment (serine, aspartate, and ribose/glucose), while the wildtype strains accumulate around necrotic zones inside tumors (Kasinskas and Forbes 2007). Moreover, various immunosuppressive mechanisms manifested by the tumor microenvironment also support the proliferation of microbes (Lin et al. 2015). 
Distinct tumor-homing property of microbes, including Lm and Salmonella, has been harnessed to deliver various tumor therapeutic modalities, including therapeutic vaccine antigens, DNA vaccines, and anticancer drugs. Various tumor-associated antigens (TAAs) have been targeted for therapeutic vaccines using LABV as delivery vehicles. PSA (prostate-specific antigen) is secreted by prostate epithelial cells and is overexpressed in malignant prostate cells. Attenuated Lm expressing PSA ( $L m$-LLO-PSA) antigen was tested as therapeutic vaccine in mouse tumor models expressing human PSA. Immunization with $L m$-LLO-PSA completely regressed tumors in five out of eight mice and induced PSA-specific cellular immune response. Immunization of $L m$-LLO-PSA significantly increased infiltration of PSA-specific $\mathrm{CD}^{+} \mathrm{T}$ cells in tumors and decrease in $\mathrm{CD} 4 / \mathrm{CD} 25 / \mathrm{FoxP}^{+} \mathrm{T}_{\text {reg }}$ cells (Wallecha et al. 2009). HER2/neu is overexpressed in about 25-30\% of breast cancers and is a potential target for immunotherapy. Shahabi et al. engineered an $L m$-based vaccine incorporating HER2/neu as antigen (ADXS31-1642). ADXS31-164 elicited HER2specific $\mathrm{CD}^{+} \mathrm{T}$ cells. The vaccine caused a significant delay in the formation of mammary tumors, and $50 \%$ of mice were tumor-free till 45 weeks of the experiment, whereas all sham-treated mice developed tumors and succumbed to the disease. This vaccine also resulted in significant increase in tumor-infiltrating $\mathrm{CD}^{+} \mathrm{T}$ cells and a decrease in the intratumoral FoxP3 ${ }^{+} \mathrm{T}_{\text {reg }}$ cells (Shahabi et al. 2011). $P$. aeruginosa can also deliver heterologous antigens using its type III secretion system. In an experimental model of B-cell melanoma expressing ovalbumin (OVA), Chauchet et al. demonstrated antitumor efficacy of $P$. aeruginosa-based vaccine expressing OVA. P. aeruginosa induced a long-lasting and polyfunctional $\mathrm{CD}^{+}$ T-cell immune response against the cognate antigen, wherein antigen-specific $\mathrm{CD}^{+}$ T cells expressed IFN $\gamma, \mathrm{TNF} \alpha$, and IL2 simultaneously. These $\mathrm{CD}^{+} \mathrm{T}$ cells also showed enhanced tumor infiltration property and a greater ratio between effector versus regulatory T cells (Chauchet et al. 2016). Recently Mei et al. utilized a composite approach of DNA vaccine and bacterial surface expression to achieve CD8 ${ }^{+}$ and $\mathrm{CD}^{+}$T-cell-mediated immunity targeted to a tumor-associated antigen. The Salmonella-based vaccine included AIDA-I autotransporter-Melan A (a murine melanoma antigen) fusion protein and a DNA vaccine element encoding two murine melanoma epitopes (Mei et al. 2017).

\subsection{Novel Technologies for Tailored and Enhanced Immune Response}

\subsubsection{Control of Gene Expression: Use of Plasmid Copy Number and In Vivo Promoters}

High levels of antigen synthesis by multicopy plasmids exert metabolic burden to LABV, which results in hyperattenuation, low colonization, loss of viability, and most importantly poor immunogenicity. Various strategies have been adapted to circumvent this problem including the use of low-copy plasmid, use of in vivo 
inducible promoters (IVIP), and use of arabinose-inducible promoters (Loessner et al. 2007). Among the first promoters introduced in LABV is $P_{\text {nir }} B$, which is activated under anaerobic conditions. $\mathrm{P}_{\mathrm{pag}} \mathrm{C}$ and $\mathrm{P}_{\mathrm{ssa}} \mathrm{G}$ are macrophage-inducible promoters from Salmonella. Dunstan directly compared the immunogenicity of antigens upon expression of antigens regulated by $\mathrm{P}_{\text {nir }} \mathrm{B}$ and $\mathrm{P}_{\mathrm{pag}} \mathrm{C}$ and found significantly higher antibody response with $\mathrm{P}_{\mathrm{pag}} \mathrm{C}$ compared to $\mathrm{P}_{\text {nir }} \mathrm{B}$ (Dunstan et al. 1999). Arnold et al. achieved differential antigen expression in vivo using in vivo inducible promoters $\mathrm{P}_{\mathrm{pag}} \mathrm{C}$, comprising variable ribosomal binding site (RBS). By this approach, strains with a high level of expression of heterologous protein exhibited low level of colonization, while a moderate amount of expression resulted in a significantly improved infection rate in mesenteric lymph nodes. A very low level of in vivo inducible antigen expression resulted in unhampered infectivity compared to the parent strain. Immunogenicity was dependent on the rate of infection, as well as the level of antigen expression. Notably, the best immune response was achieved with moderate level of antigen expression and infectivity, while high antigenexpressing strain resulted in little to no immune response. On the other hand, a moderate level of immune response was generated with high infectivity and low antigen expression (Arnold et al. 2004). Wang et al. developed a regulated delayed antigen synthesis system, consisting of $\mathrm{LaCl}$ repressor to repress transcription from $\mathrm{P}_{\text {trc }}$ during in vitro cultivation. The arabinose-regulated promoter $\mathrm{P}_{\mathrm{BAD}}$ drives LacI expression in vitro in medium supplemented with arabinose. Upon immunization and lack of external arabinose supplementation, $\mathrm{P}_{\text {trc }}$ is derepressed, leading to the synthesis of antigens. The regulated delayed antigen synthesis system induced equivalent levels of antibody and protection to that of $\mathrm{P}_{\mathrm{pag}} \mathrm{C}$-controlled antigen synthesis and better than that of $\mathrm{P}_{\mathrm{ssa}} \mathrm{G}$-controlled antigen synthesis (Wang et al. 2011).

\subsubsection{Acid Resistance}

Upon oral immunization, LABV must withstand acidic environment of the stomach for successful colonization. Enteric pathogens including E. coli, L. monocytogenes, Shigella spp., and L. lactis can tolerate extreme acidic $\mathrm{pH}$ (below $\mathrm{pH} 2.5$ ) because they possess the most potent acid resistance (AR) system known as GDAR (glutamatedependent acid resistance) pathway. Attenuated strains of $S T$ and $S T m$ have limited acid tolerance and exhibit moderate immunogenicity (Dharmasena et al. 2016a). By engineering AR components from Shigella spp., Dharmasena et al. significantly ( $10^{5}$ fold) enhanced acid tolerance of attenuated ST-Ty21a (Dharmasena et al. 2016a).

\subsubsection{Detoxification of Lipopolysaccharide}

LPS plays important role in survival and infectivity of bacteria. However, it is also involved in toxicity to the host. Various attempts at the use of LPS O- antigen mutants of STm resulted in poor attachment and intestinal invasion and survival 
following oral immunization. By regulated expression of LPS O- antigen components such that they are expressed in vitro and at the time of immunization, but soon after colonization their synthesis is stopped, it is expected to achieve maximal infectivity and minimal toxicity (Wang et al. 2013). Kong et al. engineered a Salmonella strain where LPS O- antigen synthesis genes $r f c$ and $r f a H$ are kept under the control of the promoter araC- $\mathrm{P}_{\mathrm{BAD}}$, which is tightly regulated by arabinose. This strain is highly attenuated nevertheless exhibits superior immunogenicity (Kong et al. 2009, 2010). Another approach of detoxification of Salmonella LPS included removal of 1-phosphate group from lipid A of LPS. Kong et al. introduced an inner membrane phosphatase LpxE from $F$. tularensis, which can selectively remove the 1-phosphate group from Salmonella lipid A. The resultant LPS had reduced toxicity while preserved adjuvant activity(Kong et al. 2011). See Wang et al. for a detailed review on LPS modifications in Salmonella-based LABV (Wang et al. 2013).

\subsubsection{Optimization of Virulence: Control of Safety and Immunogenicity}

Many methods employed for attenuation, although make the LABV strains less pathogenic and safe to administer at high doses, it often renders them poorly immunogenic due to their inability to circumvent physicochemical defense of the host. Moreover, inability of penetration through mucosal barrier also makes them poorly immunogenic. To circumvent this problem, Curtiss et al. generated a regulated delayed attenuation system (RDAS), which retains full virulence till the passage through gastrointestinal tract and infection of epithelial cells. In the modified RDAS strains, Salmonella virulence genes fur, PhoP/Q, rpoS, and crp are expressed under the control of araC- $\mathrm{P}_{\mathrm{BAD}}$ promoter. Arabinose concentration in human tissues is very less. Thus, in vitro these strains express all the virulence genes in medium supplemented with arabinose, whereas in vivo under the arabinose deprivation, many virulence genes are suppressed, resulting in attenuation of Salmonella. This approach results in high immunogenicity combined with tolerance at high doses (Curtiss 3rd et al. 2009).

\subsubsection{Cytosolic Delivery of Antigen}

In order to evoke $\mathrm{CD}^{+} \mathrm{T}$-cell (CTL) response, antigens need to be delivered into the cytoplasm of host cell. Various approaches are in use to accomplish the cytosolic delivery of antigens including the use of a type III secretion system that can directly deliver vaccine antigens into the host cell cytoplasm and use of a-hemolysin (HlyA) secretion system of $E$. coli which is fully active in Salmonella (Gentschev et al. 1996). On the other hand, escape from endocytic vacuoles is also a feasible approach. Unlike $L m, S T$ and $S T m$ do not reach cytoplasm of infected cells and elicit CD4 ${ }^{+}$ $\mathrm{T}$-cell response more effectively compared to $\mathrm{CD} 8^{+} \mathrm{T}$-cell response to cognate 
antigens. Chen et al. used secretion signal of a type III secretion system Salmonella outer protein E (SopE) and HlyA (secretion signal) to deliver S. japonicum antigen Sj23-LHD-GST. The Salmonella vaccine constructs carrying Sj23 LHD-GST fused to HlyA (secretion signal) or SopE effectively expressed and delivered antigens into cytoplasm of murine macrophages in vitro. This vaccine construct induced Sj23LHD-GST-specific Th1 type response and protected against $S$. japonicum infection (Chen et al. 2011). Gentschev et al. reported that two Listerial antigens delivered by STm using HlyA (secretion signal) generated protection against Listeria infection (Gentschev et al. 1996). Simultaneous delivery of two Listerial antigens (LLO and p60) by STm using Yersinia outer protein E (YopE) as a carrier molecule for Salmonella type III secretion system developed LLO- and p60-specific T cells and protection against murine listeriosis (Igwe et al. 2002). SopE-mediated delivery of Listerial antigen p60 generated $\mathrm{CD} 8^{+} \mathrm{T}$-cell-mediated protection against Listeria infection (Berchtold et al. 2009).

\subsection{Conclusion}

What makes bacteria an excellent vaccine delivery vehicle is their natural ability to induce potent and long-lasting immune response. LABVs possess the capacity to induce humoral as well as cell-mediated immune response. While the humoral immune response includes serum IgG and mucosal IgG and IgA, the cell-mediated immunity is characterized by Th1-, Th2-, and Th17-type CD4+ T cells and CD8+ CTLs. IgA and IL17 have been specifically implicated in mucosal protection against various mucosal pathogens. The cell-mediated immunity is required for intracellular pathogens. It should be noted that subunit vaccines have a poor capacity to evoke mucosal as well as cell-mediated immunity. LABVs have also shown the capacity to overcome immunosuppressive nature of various forms of tumors. These characteristic of LABVs, together with their tumor-tropic capacity, makes them a highly suitable vector for cancer immunotherapeutic vaccines. In the past two decades, tremendous progress has been made regarding LABV-mediated delivery of vaccine antigens for prevention of a variety of viral, bacterial, and parasitic diseases. Recent advances have further improved the safety and immunogenicity profile of several LABV platforms. The new-generation LABVs can withstand harsh physicochemical conditions of gastrointestinal tract, exhibit regulated attenuation, regulated antigen expression, and targeted antigen delivery. LABVs have exhibited effectiveness in various preclinical and preliminary clinical trials (Table 2.1). However, a limited number of clinical trials have been conducted to date using LABVs, due to potential safety concerns. Further optimization would result in a versatile, safe, and highly immunogenic vaccine delivery platforms. 
2 Live-Attenuated Bacterial Vectors for Delivery of Mucosal Vaccines, DNA Vaccines...

Table 2.1 Examples of vaccines delivered by live-attenuated bacterial vectors

\begin{tabular}{|c|c|c|c|c|c|}
\hline $\begin{array}{l}\text { Vaccine } \\
\text { vector }\end{array}$ & Attenuation & $\begin{array}{l}\text { Target } \\
\text { pathogen }\end{array}$ & Target antigen & $\begin{array}{l}\text { Immune } \\
\text { response }\end{array}$ & References \\
\hline \multicolumn{6}{|c|}{ Viral pathogens } \\
\hline BCG & & Hepatitis B & $\begin{array}{l}\text { Surface } \\
\text { antigens }\end{array}$ & Antibodies & Rezende et al. (2005) \\
\hline BCG & & HIV & $\begin{array}{l}\text { SIV-Gag and } \\
\text { CD8+ T-cell } \\
\text { epitopes }\end{array}$ & $\begin{array}{l}\mathrm{CD} 8+\mathrm{T} \\
\text { cell }\end{array}$ & $\begin{array}{l}\text { Venkataswamy et al. } \\
\text { (2014) and Mahant } \\
\text { et al. (2017) }\end{array}$ \\
\hline BCG & & HIV and SIV & gp120, Gag & $\mathrm{T}$ cells & Hart et al. (2015) \\
\hline L. lactis & & HPV-16-E7 & LL-E7 & $\begin{array}{l}\text { Th1 immune } \\
\text { response }\end{array}$ & Almeida et al. (2016) \\
\hline L. lactis & & H1N1 & HA & \begin{tabular}{|l|} 
IgA, \\
Antibodies
\end{tabular} & Joan et al. (2016) \\
\hline L. lactis & & H5N1 & HA & $\operatorname{IgA}$ & Bobek et al. (2010) \\
\hline \multirow[t]{3}{*}{$L m$} & $\Delta a c t \mathrm{~A} /$ & \multirow[t]{3}{*}{ H1N1 } & \multirow[t]{3}{*}{ NP } & \multirow[t]{3}{*}{ Th1 } & \multirow[t]{3}{*}{ Johnson et al. (2011) } \\
\hline & $\begin{array}{l}\Delta p l c \mathrm{~B} \text { and } \\
\Delta a c t \mathrm{~A} /\end{array}$ & & & & \\
\hline & $\Delta i n l \mathrm{~B}$ & & & & \\
\hline Lm & $\Delta d a l, \Delta d a t$ & HIV & Gag, gp160 & $\begin{array}{l}\text { CD8+, CTL, } \\
\text { nAb }\end{array}$ & $\begin{array}{l}\text { Frankel et al. (1995), } \\
\text { Friedman et al. } \\
\text { (2000), Rayevskaya } \\
\text { and Frankel (2001), } \\
\text { Rayevskaya et al. } \\
\text { (2002), Jiang et al. } \\
\text { (2007) and Lakhashe } \\
\text { et al. (2011) }\end{array}$ \\
\hline$L m$ & $\begin{array}{l}\Delta a c t \mathrm{~A} \\
\Delta p l c \mathrm{~B}\end{array}$ & HPV17 & E7 & CTL & Jia et al. (2012) \\
\hline Lm & $\Delta a c t \mathrm{~A}$ & LCMV & NP118-126 & $\begin{array}{l}\text { CD8+ T } \\
\text { cells }\end{array}$ & $\begin{array}{l}\text { Tvinnereim et al. } \\
(2002)\end{array}$ \\
\hline Lm & $\Delta d a l, \Delta d a t$ & SIV & Gag & $\begin{array}{l}\text { CD8+, } \\
\text { Cellular } \\
\text { immune } \\
\text { response }\end{array}$ & $\begin{array}{l}\text { Sciaranghella et al. } \\
\text { (2011) and Im et al. } \\
\text { (2013) }\end{array}$ \\
\hline STm & $\Delta$ aroA & Dengue virus & NS3-MisL & CTL & $\begin{array}{l}\text { Luria-Perez et al. } \\
(2007)\end{array}$ \\
\hline STm & $\begin{array}{l}\Delta c p x \mathrm{R}, \\
\Delta l o n, \Delta a s d \\
\text { and } \Delta w b a \mathrm{P}\end{array}$ & H1N1 & $\mathrm{HA}$ and $\mathrm{M} 2 \mathrm{e}$ & $\begin{array}{l}\text { IgG1 and } \\
\text { IgG2a and } \\
\text { Th1 cell } \\
\text { response }\end{array}$ & Hajam and Lee (2017) \\
\hline STm & $\Delta$ aroA & H5N1 & HA, NA, NP & $\begin{array}{l}\text { IgG and } \\
\text { mucosal } \\
\text { IgA and } \\
\text { gamma- } \\
\text { producing T } \\
\text { cells }\end{array}$ & $\begin{array}{l}\text { Ashraf et al. (2011) } \\
\text { and Pei et al. (2015) }\end{array}$ \\
\hline
\end{tabular}


Table 2.1 (continued)

\begin{tabular}{|c|c|c|c|c|c|}
\hline $\begin{array}{l}\text { Vaccine } \\
\text { vector }\end{array}$ & Attenuation & $\begin{array}{l}\text { Target } \\
\text { pathogen }\end{array}$ & Target antigen & $\begin{array}{l}\text { Immune } \\
\text { response }\end{array}$ & References \\
\hline STm & $\Delta$ aro $\mathrm{C}$ & HIV-1 & 10- E8, Gag & $\begin{array}{l}\text { Antibody, } \\
\text { CTL }\end{array}$ & $\begin{array}{l}\text { Karpenko et al. } \\
\text { (2004), Chin'ombe } \\
\text { and Ruhanya (2013), } \\
\text { Li et al. (2016) }\end{array}$ \\
\hline STm & $\Delta$ aroA & Measles virus & $\begin{array}{l}\text { B-cell and } \\
\text { T-cell epitopes }\end{array}$ & $\operatorname{IgG}$ & Spreng et al. (2000) \\
\hline$S T$ & $\Delta p i l \mathrm{~S}$ & SARS & $\begin{array}{l}\text { Nucleocapsid } \\
\text { protein }\end{array}$ & $\begin{array}{l}\text { IgG2a and } \\
\text { IgA }\end{array}$ & Luo et al. (2007) \\
\hline STm & $\Delta$ aroA & TGEV & $\begin{array}{l}\mathrm{N} \text { gene, } \mathrm{C} \text { and } \\
\mathrm{A} \text { epitopes }\end{array}$ & $\operatorname{IgG}$ & $\begin{array}{l}\text { Chen and Schifferli } \\
(2003,2007) \text { and } \\
\text { Zhang et al. (2016a) }\end{array}$ \\
\hline \multicolumn{6}{|c|}{ Bacterial pathogens } \\
\hline BCG & & B. pertussis & $\begin{array}{l}\text { Pertussis toxin } \\
\text { Subunit S1 }\end{array}$ & Th1 & $\begin{array}{l}\text { Nascimento et al. } \\
(2008,2009)\end{array}$ \\
\hline BCG & & $L m$ & p60 Ag & $\begin{array}{l}\text { CD4 and } \\
\text { CD8 T cell }\end{array}$ & Grode et al. (2002) \\
\hline BCG & & $M t b$ & $\mathrm{Ag} 85 \mathrm{~B}$ & $\begin{array}{l}\text { IL 17A T } \\
\text { cells }\end{array}$ & Hatano et al. (2016) \\
\hline BCG & & $\begin{array}{l}\text { B. pertussis, } \\
\text { tetanus, } M t b\end{array}$ & $\begin{array}{l}\text { Pertussis- } \\
\text { tetanus toxin } \\
\text { fusion }\end{array}$ & $\begin{array}{l}\text { Humoral } \\
\text { and cellular }\end{array}$ & $\begin{array}{l}\text { Abomoelak et al. } \\
\text { (1999) }\end{array}$ \\
\hline BCG & & S. pneumoniae & PspA & $\begin{array}{l}\text { IL-17A and } \\
\text { IFNg }\end{array}$ & Goulart et al. (2017) \\
\hline $\begin{array}{l}\text { B. } \\
\text { subtilis }\end{array}$ & & ETEC & $\mathrm{CfaB}$ & $\begin{array}{l}\text { Sera and } \\
\text { mucosal } \mathrm{Ab}\end{array}$ & $\begin{array}{l}\text { Amuguni and Tzipori } \\
\text { (2012) }\end{array}$ \\
\hline $\begin{array}{l}\text { B. } \\
\text { subtilis }\end{array}$ & & H. pylori & Urease B & $\begin{array}{l}\text { IgG, IgA, } \\
\text { Th1/Th17 }\end{array}$ & $\begin{array}{l}\text { Stasilojc et al. (2015) } \\
\text { and Zhou et al. (2015) }\end{array}$ \\
\hline $\begin{array}{l}\text { B. } \\
\text { subtilis }\end{array}$ & & $M t b$ & MPT64 & Th1 & Sibley et al. (2014) \\
\hline $\begin{array}{l}\text { B. } \\
\text { subtilis }\end{array}$ & & Tetanus & TT C fragment & $\operatorname{IgG}, \operatorname{Ig} \mathrm{A}$ & Amuguni et al. (2011) \\
\hline E. coli & $\begin{array}{l}\Delta \text { intimin, } \\
\Delta s t x 1 \text { and } \\
\Delta s t x 2\end{array}$ & ETEC & $\begin{array}{l}\text { CFA-I, } \\
\text { LThK63 }\end{array}$ & $\operatorname{IgG}$ and $\operatorname{Ig} \mathrm{A}$ & $\begin{array}{l}\text { Byrd and Boedeker } \\
\text { (2013) }\end{array}$ \\
\hline E. coli & $\Delta l e r$ & EHEC & Stx1B & Antibody & Zhu et al. (2006) \\
\hline L. casei & & C. perfringens & Epsilon & IgG, IgA & $\begin{array}{l}\text { Alimolaei et al. } \\
\text { (2016) }\end{array}$ \\
\hline L. lactis & & C. jejuni & cjAD & Antibody & $\begin{array}{l}\text { Kobierecka et al. } \\
(2016)\end{array}$ \\
\hline L. lactis & & C. difficile & TETC-TcdA & Antibodies & Yang et al. (2013) \\
\hline L. lactis & & H. pylori & $\begin{array}{l}\text { Omp22 or } \\
\text { HpaA, cag12, } \\
\text { urease B }\end{array}$ & Antibody & $\begin{array}{l}\text { Gu et al. (2009), Kim } \\
\text { et al. (2009), Li et al. } \\
\text { (2014), and Zhang } \\
\text { et al. (2016b) }\end{array}$ \\
\hline
\end{tabular}


Table 2.1 (continued)

\begin{tabular}{|c|c|c|c|c|c|}
\hline $\begin{array}{l}\text { Vaccine } \\
\text { vector }\end{array}$ & Attenuation & $\begin{array}{l}\text { Target } \\
\text { pathogen }\end{array}$ & Target antigen & $\begin{array}{l}\text { Immune } \\
\text { response }\end{array}$ & References \\
\hline L. lactis & & $\begin{array}{l}\text { L. } \\
\text { monocytogenes }\end{array}$ & Listeriolysin $\mathrm{O}$ & $\begin{array}{l}\text { CD8+ T } \\
\text { cells }\end{array}$ & $\begin{array}{l}\text { Bahey-El-Din et al. } \\
(2008)\end{array}$ \\
\hline L. lactis & & S. pyogenes & $\begin{array}{l}\text { M protein } \\
\text { (CRR) }\end{array}$ & $\begin{array}{l}\text { Mucosal } \\
\text { IgA }\end{array}$ & $\begin{array}{l}\text { Mannam et al. (2004) } \\
\text { and Mannam et al. } \\
\text { (2004) }\end{array}$ \\
\hline L. lactis & & V. cholera & Wzm & $\operatorname{IgG}$ and $\operatorname{IgA}$ & Zamri et al. (2012) \\
\hline Lm & $\begin{array}{l}\Delta a c t \mathrm{~A} \\
\Delta i n l \mathrm{~B}\end{array}$ & C. burnetii & $\begin{array}{l}\text { T4SS } \\
\text { (Epitopes) }\end{array}$ & $\begin{array}{l}\mathrm{CD} 8+\mathrm{T} \\
\text { cells }\end{array}$ & Xiong et al. (2017) \\
\hline$S T$ & $\begin{array}{l}\Delta a r o \mathrm{C}, \\
\Delta a r o \mathrm{D}, \text { and } \\
\Delta h t r \mathrm{~A}\end{array}$ & B. anthracis & PA83, PAd4 & IgG, Ifng & $\begin{array}{l}\text { Galen et al. (2004, } \\
\text { 2010) }\end{array}$ \\
\hline STm & $\triangle a r o \mathrm{~A}$ & B. pertussis & $\begin{array}{l}\text { Pertussis toxins } \\
\text { S1, S2, S3, S4, } \\
\text { and S5 }\end{array}$ & $\mathrm{IgG}$ & $\begin{array}{l}\text { Dalla Pozza et al. } \\
\text { (1998) }\end{array}$ \\
\hline STm & $\begin{array}{l}\Delta l o n, \\
\Delta c p x \mathrm{R}\end{array}$ & B. abortus & $\begin{array}{l}\text { BCSP31, } \\
\text { Omp3b, and } \\
\text { SOD }\end{array}$ & $\begin{array}{l}\operatorname{IgG} \text { and } \\
\operatorname{sIg} A\end{array}$ & $\begin{array}{l}\text { Kim et al. (2016) and } \\
\text { Lalsiamthara and Lee } \\
\text { (2017) }\end{array}$ \\
\hline STm & $\begin{array}{l}\Delta \operatorname{aro} \mathrm{C}, \\
\Delta a r o \mathrm{D} \text { and } \\
\Delta h t r \mathrm{~A}\end{array}$ & $\begin{array}{l}\text { EHEC } \\
\text { O157:H7 }\end{array}$ & $\begin{array}{l}\text { Intimin, CFA-I, } \\
\text { CS3, STx2 }\end{array}$ & $\begin{array}{l}\text { Mucosal } \\
\text { IgG and IgA }\end{array}$ & $\begin{array}{l}\text { Girón et al. (1995), } \\
\text { Rojas et al. (2010) } \\
\text { and Ferreira Oliveira } \\
\text { et al. (2012) }\end{array}$ \\
\hline STm & $\Delta \mathrm{PhoP} / \mathrm{Q}$ & H. pylori & $\begin{array}{l}\text { Urease B, } \\
\text { hpaA, adhesin } \\
\text { AB, babA2/ } \\
\text { ureI, CagA, } \\
\text { and VacA }\end{array}$ & Antibodies & $\begin{array}{l}\text { Angelakopoulos and } \\
\text { Hohmann (2000), Bai } \\
\text { et al. (2004), Xu et al. } \\
\text { (2005) and Liu et al. } \\
\text { (2011) }\end{array}$ \\
\hline STm & $\begin{array}{l}\Delta \operatorname{aro\mathrm {A}/} \\
\Delta \operatorname{spt\mathrm {P}}\end{array}$ & $\begin{array}{l}\text { L. } \\
\text { monocytogenes }\end{array}$ & $\begin{array}{l}\text { Listeriolysin } \\
\text { and p60 }\end{array}$ & $\begin{array}{l}\text { CD8+ T } \\
\text { cell, IFNg }\end{array}$ & $\begin{array}{l}\text { Igwe et al. (2002), } \\
\text { Sevil Domènech et al. } \\
\text { (2008) and Berchtold } \\
\text { et al. (2009) }\end{array}$ \\
\hline STm & $\Delta \operatorname{aroA}$ & $M t b$ & ESAT6-Ag85B & T cell, IFNg & Wang et al. (2009) \\
\hline$S T m$ & $\begin{array}{l}\Delta \operatorname{aroC}, \\
\Delta a r o \mathrm{D}, \text { and } \\
\Delta h t r \mathrm{~A}\end{array}$ & P. aeruginosa & $\begin{array}{l}\text { OprF/OprI, } \\
\text { LPS }\end{array}$ & $\begin{array}{l}\text { Antibodies } \\
\text { and TH1, } \\
\text { mucosal } \\
\text { IgG, and } \\
\text { IgA }\end{array}$ & $\begin{array}{l}\text { Arnold et al. (2004), } \\
\text { Digiandomenico et al. } \\
\text { (2004) and Bumann } \\
\text { et al. (2010) }\end{array}$ \\
\hline STm & $\begin{array}{l}\Delta c y a \text { and } \\
\Delta c r p\end{array}$ & P. gingivalis & HagB & $\begin{array}{l}\text { IgG and IgA } \\
\text { and mucosal } \\
\text { IgA }\end{array}$ & $\begin{array}{l}\text { Isoda et al. (2007) and } \\
\text { Pathangey et al. } \\
\text { (2009) }\end{array}$ \\
\hline STm & $\Delta g a l \mathrm{E}$ & S. dysenteriae & LPS & $\begin{array}{l}\text { Serum } \\
\text { antibody }\end{array}$ & $\begin{array}{l}\text { Dharmasena et al. } \\
(2016 b)\end{array}$ \\
\hline STm & $\Delta g a l \mathrm{E}$ & S. sonnei & LPS & $\begin{array}{l}\text { Serum } \\
\text { antibody }\end{array}$ & $\begin{array}{l}\text { Dharmasena et al. } \\
\text { (2013) }\end{array}$ \\
\hline
\end{tabular}


Table 2.1 (continued)

\begin{tabular}{|c|c|c|c|c|c|}
\hline $\begin{array}{l}\text { Vaccine } \\
\text { vector }\end{array}$ & Attenuation & $\begin{array}{l}\text { Target } \\
\text { pathogen }\end{array}$ & Target antigen & $\begin{array}{l}\text { Immune } \\
\text { response }\end{array}$ & References \\
\hline STm & $\begin{array}{l}\Delta c r p \text { and } \\
\Delta a s d \mathrm{~A}\end{array}$ & S. pneumoniae & PspA, PspC & $\begin{array}{l}\text { Th1/Th2, } \\
\text { IgG, and } \\
\text { IgA }\end{array}$ & $\begin{array}{l}\text { Kang et al. (2002), } \\
\text { Xin et al. (2009), Shi } \\
\text { et al. (2010), Wang } \\
\text { et al. (2010, 2011), } \\
\text { Kong et al. (2011) and } \\
\text { Frey et al. (2013) }\end{array}$ \\
\hline$S T$ & $\begin{array}{l}\Delta \operatorname{aroC}, \\
\Delta \operatorname{aro}, \text { and } \\
\Delta h t r \mathrm{~A}\end{array}$ & Tetanus & TetC & IgG, IgA & $\begin{array}{l}\text { Dunstan et al. (1999), } \\
\text { Allen et al. (2000), } \\
\text { Orr et al. (2001) and } \\
\text { Capozzo et al. (2004) }\end{array}$ \\
\hline STm & $\Delta$ aroA & $\begin{array}{l}Y . \\
\text { enterocolitica }\end{array}$ & HSP-60 & T cell, IFNg & Kramer et al. (2003) \\
\hline STm & $\Delta \mathrm{PhoP} / \mathrm{Q}$ & Y.pestis & $\begin{array}{l}\text { F1, V, YadC, } \\
\text { YadBC, PsaA, } \\
\text { LcrV, Psn, and } \\
\text { HmuR }\end{array}$ & $\begin{array}{l}\text { IgG, CD4, } \\
\text { and CD8+ T } \\
\text { cells }\end{array}$ & $\begin{array}{l}\text { Ramirez et al. (2009), } \\
\text { Branger et al. (2010), } \\
\text { Torres-Escobar et al. } \\
\text { (2010), Sizemore } \\
\text { et al. (2012), Sun } \\
\text { et al. (2014) and } \\
\text { Galen et al. (2015) }\end{array}$ \\
\hline $\begin{array}{l}S . \\
\text { flexneri }\end{array}$ & $\Delta g u a \mathrm{BA}$ & ETEC & $\begin{array}{l}\text { CFA-I and } \\
\text { LTB, CS2, } \\
\text { CS3, CS4, and } \\
\text { CFA/A }\end{array}$ & $\begin{array}{l}\text { Serum IgG } \\
\text { and mucosal } \\
\text { IgA }\end{array}$ & $\begin{array}{l}\text { Koprowski et al. } \\
\text { (2000), Barry et al. } \\
\text { (2003), Ranallo et al. } \\
\text { (2005) and Zheng } \\
\text { et al. (2005) }\end{array}$ \\
\hline $\begin{array}{l}\text { V. } \\
\text { cholerae }\end{array}$ & $\Delta c t x$ & C. difficile & TcdA & $\operatorname{IgG}$ & Ryan et al. (1997) \\
\hline $\begin{array}{l}\text { V. } \\
\text { cholerae }\end{array}$ & $\Delta a t t \mathrm{RS} 1$ & E. coli & LT & $\begin{array}{l}\text { Serum IgG } \\
\text { and mucosal } \\
\text { IgA }\end{array}$ & Ryan et al. (1999) \\
\hline $\begin{array}{l}\text { V. } \\
\text { cholerae }\end{array}$ & $\Delta \mathrm{CTA}$ & H. pylori & $\mathrm{HpaA}$ & $\operatorname{IgG}$ & Tobias et al. (2017) \\
\hline $\begin{array}{l}\text { V. } \\
\text { cholerae }\end{array}$ & $\begin{array}{l}\text { Naturally } \\
\text { attenuated }\end{array}$ & $\begin{array}{l}\text { Tetanus toxin, } \\
B . \text { pertussis }\end{array}$ & TetC, BP-TCF & $\operatorname{IgG}$ & Chen et al. (1998) \\
\hline \multicolumn{6}{|c|}{ Parasitic pathogens } \\
\hline \begin{tabular}{l|} 
B. \\
subtilis
\end{tabular} & & C. sinensis & Enolase & \begin{tabular}{|l|} 
Mucosal \\
IgG and $\operatorname{IgA}$ \\
\end{tabular} & Yu et al. (2015) \\
\hline $\begin{array}{l}\text { B. } \\
\text { subtilis }\end{array}$ & & S. japonicum & GST protein & $\begin{array}{l}\text { Mucosal } \\
\text { IgG and IgA }\end{array}$ & Li et al. (2009) \\
\hline E. coli & $\Delta l e r$ & Malaria & NANP & Antibody & Zhu et al. (2006) \\
\hline Lm & $\Delta a c t \mathrm{~A}$ & L. major & $\begin{array}{l}\text { LJM11, p36, } \\
\text { and LACK }\end{array}$ & Th1 & $\begin{array}{l}\text { Soussi et al. (2002), } \\
\text { Saklani-Jusforgues } \\
\text { et al. (2003) and Abi } \\
\text { Abdallah et al. (2014) }\end{array}$ \\
\hline
\end{tabular}


Table 2.1 (continued)

\begin{tabular}{|c|c|c|c|c|c|}
\hline $\begin{array}{l}\text { Vaccine } \\
\text { vector }\end{array}$ & Attenuation & $\begin{array}{l}\text { Target } \\
\text { pathogen }\end{array}$ & Target antigen & $\begin{array}{l}\text { Immune } \\
\text { response }\end{array}$ & References \\
\hline STm & $\begin{array}{l}\Delta p m i, \Delta f u r \\
\text { and } \Delta c r p\end{array}$ & G. lamblia & $\begin{array}{l}\alpha 1 \text {-Giardin, } \\
\text { CWP2 }\end{array}$ & $\begin{array}{l}\text { Th1/Th2, } \\
\text { mucosal } \\
\text { IgG, and } \\
\text { IgA }\end{array}$ & $\begin{array}{l}\text { Abdul-Wahid and } \\
\text { Faubert (2007) and } \\
\text { Jenikova et al. (2011) }\end{array}$ \\
\hline STm & $\begin{array}{l}\Delta \operatorname{aro} \mathrm{C}, \\
\Delta \operatorname{aro\mathrm {D}}, \text { and } \\
\Delta h t r \mathrm{~A}\end{array}$ & C. parvum & $\begin{array}{l}\text { Cp23, CP15, } \\
\text { and Cp40 }\end{array}$ & Antibody & $\begin{array}{l}\text { Benitez et al. (2009) } \\
\text { and Roche et al. } \\
(2013)\end{array}$ \\
\hline STm & $\Delta$ aroA & E. histolytica & $\begin{array}{l}\text { Gal/Gal-NAC } \\
\text { lectin }\end{array}$ & Antibody & Mann et al. (1997) \\
\hline$S T$ & $\begin{array}{l}\Delta a r o \mathrm{C} \text { and } \\
\Delta a r o \mathrm{D}\end{array}$ & L. mexicana & gp63 & $\begin{array}{l}\text { Th1 type } \\
\text { immunity }\end{array}$ & González et al. (1998) \\
\hline STm & $\begin{array}{l}\Delta p u r l \text { and } \\
\Delta m s b \mathrm{~B}\end{array}$ & S. japonicum & Sj23LHD-GST & $\begin{array}{l}\text { Th1 type } \\
\text { immunity }\end{array}$ & Chen et al. (2011) \\
\hline STm & $\begin{array}{l}\Delta c r p \text { and } \\
\Delta c y a\end{array}$ & T. solium & TSOL18 & $\begin{array}{l}\text { CD4 and } \\
\text { CD8 T cells }\end{array}$ & Ding et al. (2013) \\
\hline
\end{tabular}

\section{References}

Abdul-Wahid A, Faubert G (2007) Mucosal delivery of a transmission-blocking DNA vaccine encoding Giardia lamblia CWP2 by Salmonella typhimurium bactofection vehicle. Vaccine 25(50):8372-8383. https://doi.org/10.1016/j.vaccine.2007.10.012

Abi Abdallah DS, Bitar AP, Oliveira F, Meneses C, Park JJ, Mendez S et al (2014) A Listeria monocytogenes-based vaccine that secretes sand fly salivary protein LJM11 confers longterm protection against vector-transmitted Leishmania major. Infect Immun 82(7):2736-2745. https://doi.org/10.1128/iai.01633-14

Abomoelak B, Huygen K, Kremer L, Turneer M, Locht C (1999) Humoral and cellular immune responses in mice immunized with recombinant Mycobacterium bovis Bacillus Calmette-Guérin producing a pertussis toxin-tetanus toxin hybrid protein. Infect Immun 67(10):5100-5105

Alimolaei M, Golchin M, Daneshvar H (2016) Oral immunization of mice against Clostridium perfringens epsilon toxin with a Lactobacillus casei vector vaccine expressing epsilon toxoid. Infect Genet Evol 40:282-287. https://doi.org/10.1016/j.meegid.2016.03.020

Allen JS, Dougan G, Strugnell RA (2000) Kinetics of the mucosal antibody secreting cell response and evidence of specific lymphocyte migration to the lung after oral immunisation with attenuated S. enterica var. typhimurium. FEMS Immunol Med Microbiol 27(4):275-281. https://doi. org/10.1016/s0928-8244(99)00204-7

Almeida JF, Breyner NM, Mahi M, Ahmed B, Benbouziane B, Boas PCBV et al (2016) Expression of fibronectin binding protein A (FnBPA) from Staphylococcus aureus at the cell surface of Lactococcus lactis improves its immunomodulatory properties when used as protein delivery vector. Vaccine 34(10):1312-1318. https://doi.org/10.1016/j.vaccine.2016.01.022

Amuguni H, Tzipori S (2012) Bacillus subtilis: a temperature resistant and needle free delivery system of immunogens. Hum Vaccin Immunother 8(7):979-986. https://doi.org/10.4161/hv.20694

Amuguni JH, Lee S, Kerstein KO, Brown DW, Belitsky BR, Herrmann JE et al (2011) Sublingually administered Bacillus subtilis cells expressing tetanus toxin $\mathrm{C}$ fragment induce protective systemic and mucosal antibodies against tetanus toxin in mice. Vaccine 29(29-30):4778-4784. https://doi.org/10.1016/j.vaccine.2011.04.083 
Angelakopoulos H, Hohmann EL (2000) Pilot study of phoP/phoQ-deleted Salmonella enterica serovar typhimurium expressing Helicobacter pylori urease in adult volunteers. Infect Immun 68(4):2135-2141. https://doi.org/10.1128/IAI.68.4.2135-2141.2000.Updated

Arnold H, Bumann D, Felies M, Gewecke B, Sörensen M, Gessner JE et al (2004) Enhanced immunogenicity in the murine airway mucosa with an attenuated Salmonella live vaccine expressing OprF-OprI from Pseudomonas aeruginosa. Infect Immun 72(11):6546-6553. https://doi.org/10.1128/iai.72.11.6546-6553.2004

Ashraf S, Kong W, Wang S, Yang J, Curtiss R (2011) Protective cellular responses elicited by vaccination with influenza nucleoprotein delivered by a live recombinant attenuated Salmonella vaccine. Vaccine 29(23):3990-4002. https://doi.org/10.1016/j.vaccine.2011.03.066

Bahey-El-Din M, Casey PG, Griffin BT, Gahan CGM (2008) Lactococcus lactis-expressing listeriolysin O (LLO) provides protection and specific CD8(+) T cells against Listeria monocytogenes in the murine infection model. Vaccine 26(41):5304-5314. https://doi.org/10.1016/j. vaccine.2008.07.047

Bai Y, Zhang YL, Wang JD, Zhang ZS, Zhou DY (2004) Construction of attenuated Salmonella typhimurium strain expressing Helicobacter pylori conservative region of adhesin antigen and its immunogenicity. World J Gastroenterol 10(17):2498-2502

Barry EM, Altboum Z, Losonsky G, Levine MM (2003) Immune responses elicited against multiple enterotoxigenic Escherichia coli fimbriae and mutant LT expressed in attenuated Shigella vaccine strains. Vaccine 21(5-6):333-340. https://doi.org/10.1016/s0264-410x(02)00611-4

Benitez AJ, McNair N, Mead JR (2009) Oral immunization with attenuated Salmonella enterica serovar typhimurium encoding Cryptosporidium parvum $\mathrm{Cp} 23$ and $\mathrm{Cp} 40$ antigens induces a specific immune response in mice. Clin Vaccine Immunol 16(9):1272-1278. https://doi. org/10.1128/cvi.00089-09

Berchtold C, Panthel K, Jellbauer S, Köhn B, Roider E, Partilla M et al (2009) Superior protective immunity against murine listeriosis by combined vaccination with CpG DNA and recombinant Salmonella enterica serovar typhimurium. Infect Immun 77(12):5501-5508. https://doi. org/10.1128/iai.00700-09

Bermúdez-Humarán LG, Kharrat P, Chatel J-M, Langella P (2011) Lactococci and lactobacilli as mucosal delivery vectors for therapeutic proteins and DNA vaccines. Microb Cell Factories 10(Suppl 1):S4-S4. https://doi.org/10.1186/1475-2859-10-s1-s4

Bickels J, Kollender Y, Merinsky O, Meller I (2002) Coley's toxin: historical perspective. Isr Med Assoc J 4(6):471-472

Bobek V, Kolostova K, Pinterova D, Kacprzak G, Adamiak J, Kolodziej J et al (2010) A clinically relevant, syngeneic model of spontaneous, highly metastatic B16 mouse melanoma. J Med Virol 30(12):4799-4804. https://doi.org/10.1002/jmv

Branger CG, Sun W, Torres-Escobar A, Perry R, Roland KL, Fetherston J et al (2010) Evaluation of Psn, HmuR and a modified LcrV protein delivered to mice by live attenuated Salmonella as a vaccine against bubonic and pneumonic Yersinia pestis challenge. Vaccine 29(2):274-282. https://doi.org/10.1016/j.vaccine.2010.10.033

Brockstedt DG, Giedlin MA, Leong ML, Bahjat KS, Gao Y, Luckett W et al (2004) Listeriabased cancer vaccines that segregate immunogenicity from toxicity. Proc Natl Acad Sci 101(38):13832-13837. https://doi.org/10.1073/pnas.0406035101

Broz P, Ohlson MB, Monack DM (2012) Innate immune response to Salmonella typhimurium, a model enteric pathogen. Gut Microbes 3(2):62-70. https://doi.org/10.4161/gmic.19141

Bumann D, Behre C, Behre K, Herz S, Gewecke B, Gessner JE et al (2010) Systemic, nasal and oral live vaccines against Pseudomonas aeruginosa: a clinical trial of immunogenicity in lower airways of human volunteers. Vaccine 28(3):707-713. https://doi.org/10.1016/j. vaccine.2009.10.080

Byrd W, Boedeker EC (2013) Attenuated Escherichia coli strains expressing the colonization factor antigen I (CFA/I) and a detoxified heat-labile enterotoxin (LThK63) enhance clearance of ETEC from the lungs of mice and protect mice from intestinal ETEC colonization 
and LT-induced f. Vet Immunol Immunopathol 152(1-2):57-67. https://doi.org/10.1016/j. vetimm.2012.10.001

Capozzo AVE, Cuberos L, Levine MM, Pasetti MF (2004) Mucosally delivered Salmonella live vector vaccines elicit potent immune responses against a foreign antigen in neonatal mice born to naive and immune mothers.pdf. Infect Immun 72(8):4637-4646. https://doi.org/10.1128/ iai.72.8.4637

Chauchet X, Hannani D, Djebali S, Laurin D, Polack B, Marvel J et al (2016) Poly-functional and long-lasting anticancer immune response elicited by a safe attenuated Pseudomonas aeruginosa vector for antigens delivery. Mol Ther Oncolytics 3(August):16033-16033. https://doi. org/10.1038/mto.2016.33

Chen H, Schifferli DM (2003) Construction, characterization, and immunogenicity of an attenuated Salmonella enterica serovar typhimurium pgtE vaccine expressing fimbriae with integrated viral epitopes from the spiC promoter. Infect Immun 71(8):4664-4673. https://doi. org/10.1128/iai.71.8.4664-4673.2003

Chen H, Schifferli DM (2007) Comparison of a fimbrial versus an autotransporter display system for viral epitopes on an attenuated Salmonella vaccine vector. Vaccine 25(9):1626-1633. https://doi.org/10.1016/j.vaccine.2006.11.006

Chen I, Finn TM, Yanqing L, Guoming Q, Rappuoli R, Pizza M (1998) A recombinant live attenuated strain of Vibrio cholerae induces immunity against tetanus toxin and Bordetella pertussis tracheal colonization factor. Infect Immun 66(4):1648-1653

Chen G, Dai Y, Chen J, Wang X, Tang B, Zhu Y et al (2011) Oral delivery of the Sj23LHD-GST antigen by Salmonella typhimurium type III secretion system protects against Schistosoma japonicum infection in mice. PLoS Negl Trop Dis 5(9):1-11. https://doi.org/10.1371/journal. pntd.0001313

Chen YY, Lin CW, Huang WF, Chang JR, Su IJ, Hsu CH et al (2017) Recombinant bacille Calmette???Guerin coexpressing Ag85b, CFP10, and interleukin-12 elicits effective protection against Mycobacterium tuberculosis. J Microbiol Immunol Infect 50(1):90-96. https://doi. org/10.1016/j.jmii.2014.11.019

Chin'ombe N, Ruhanya V (2013) Recombinant Salmonella bacteria vectoring HIV/AIDS vaccines. Open Virol J 7:121-126. https://doi.org/10.2174/1874357901307010121

Curtiss R 3rd, Wanda SY, Gunn BM, Zhang X, Tinge SA, Ananthnarayan V et al (2009) Salmonella enterica serovar typhimurium strains with regulated delayed attenuation in vivo. Infect Immun 77(3):1071-1082. https://doi.org/10.1128/IAI.00693-08

Cutting SM, Hong HA, Baccigalupi L, Ricca E (2009) Oral vaccine delivery by recombinant spore probiotics. Int Rev Immunol 28:487-505. https://doi.org/10.3109/08830180903215605

Dalla Pozza T, Yan H, Meek D, Guzmán CA, Walker MJ (1998) Construction and characterisation of Salmonella typhimurium aroA simultaneously expressing the five pertussis toxin subunits. Vaccine 16(5):522-529. https://doi.org/10.1016/s0264-410x(97)80006-0

Dharmasena MN, Hanisch BW, Wai TT, Kopecko DJ (2013) Stable expression of Shigella sonnei form I O-polysaccharide genes recombineered into the chromosome of live Salmonella oral vaccine vector Ty21a. Int J Med Microb 303(3):105-113. https://doi.org/10.1016/j. ijmm.2013.01.001

Dharmasena MN, Feuille CM, Starke CEC, Bhagwat AA, Stibitz S, Kopecko DJ (2016a) Development of an acid-resistant Salmonella Typhi Ty21a attenuated vector for improved oral vaccine delivery. PLoS ONE 11(9):1-23. https://doi.org/10.1371/journal.pone.0163511

Dharmasena MN, Osorio M, Filipova S, Marsh C, Stibitz S, Kopecko DJ (2016b) Stable expression of Shigella dysenteriae serotype $1 \mathrm{O}$-antigen genes integrated into the chromosome of live Salmonella oral vaccine vector Ty21a. Pathog Dis 74(8):ftw098-ftw098. https://doi. org/10.1093/femspd/ftw098

Digiandomenico A, Rao J, Joanna B, Goldberg JB (2004) Oral vaccination of BALB/c mice with Salmonella enterica serovar Typhimurium expressing Pseudomonas aeruginosa $\mathrm{O}$ antigen promotes increased survival in an acute fatal pneumonia model. Infect Immun 72(12):7012-7021. https://doi.org/10.1128/iai.72.12.7012 
Ding J, Zheng Y, Wang Y, Dou Y, Chen X, Zhu X et al (2013) Immune responses to a recombinant attenuated Salmonella typhimurium strain expressing a Taenia solium oncosphere antigen TSOL18. Comp Immunol Microbiol Infect Dis 36(1):17-23. https://doi.org/10.1016/j. cimid.2012.09.006

Dunstan SJ, Simmons CP, Strugnell RA (1999) Use of in vivo-regulated promoters to deliver antigens from attenuated Salmonella enterica var. typhimurium. Infect Immun 67(10):5133-5141

Fernandez MI, Sansonetti PJ (2003) Shigella interaction with intestinal epithelial cells determines the innate immune response in shigellosis. Int J Med Microbiol 293(1):55-67. https://doi. org/10.1078/1438-4221-00244

Ferreira Oliveira A, Almeida Cardoso S, Bruno dos Reis Almeida F, Licursi de Oliveira L, Pitondo-Silva A, Gomes Soares S et al (2012) Oral immunization with attenuated Salmonella vaccine expressing Escherichia coli O157: H7 intimin gamma triggers both systemic and mucosal humoral immunity in mice. Microbiol Immunol 56(8):513-522. https://doi. org/10.1111/j.1348-0421.2012.00477.x

Forbes NS, Munn LL, Fukumura D, Jain RK (2003) Sparse initial entrapment of systemically injected Salmonella typhimurium leads to heterogeneous accumulation within tumors 1 . Cancer Res 63:5188-5193

Fraillery D, Baud D, Pang SYY, Schiller J, Bobst M, Zosso N et al (2007) Salmonella enterica serovar Tphi Ty21a expressing human papillomavirus type $16 \mathrm{~L} 1$ as a potential live vaccine against cervical cancer and typhoid fever. Clin Vaccine Immunol 14(10):1285-1295. https:// doi.org/10.1128/cvi.00164-07

Frankel FR, Hegde S, Lieberman J, Paterson Y (1995) Induction of cell-mediated immune responses to human immunodeficiency virus type 1 Gag protein by using Listeria monocytogenes as a live vaccine vector. $J$ Immunol 155(10):4775-4782

Frey SE, Lottenbach KR, Hill H, Blevins TP, Yu Y, Zhang Y et al (2013) A Phase I, dose-escalation trial in adults of three recombinant attenuated Salmonella Typhi vaccine vectors producing Streptococcus pneumoniae surface protein antigen PspA. Vaccine 31(42):4874-4880. https:// doi.org/10.1016/j.vaccine.2013.07.049

Friedman RS, Frankel FR, Xu Z, Lieberman J (2000) Induction of human immunodeficiency virus (HIV)-specific CD8 T-cell responses by Listeria monocytogenes and a hyperattenuated Listeria strain engineered to express HIV antigens. J Virol 74(21):9987-9993. https://doi.org/10.1128/ jvi.74.21.9987-9993.2000

Fuge O, Vasdev N, Allchorne P, Green JS (2015) Immunotherapy for bladder cancer. Res Rep Urol 7:65-79. https://doi.org/10.2147/rru.s63447

Galán JE, Nakayama K, Curtiss R (1990) Cloning and characterization of the asd gene of Salmonella typhimurium: use in stable maintenance of recombinant plasmids in Salmonella vaccine strains. Gene 94(1):29-35. https://doi.org/10.1016/0378-1119(90)90464-3

Galen JE, Nair J, Wang JY, Steven S, Tanner MK, Sztein MB et al (1999) Optimization of plasmid maintenance in the attenuated live vector vaccine strain Salmonella typhi CVD 908htrA. Infect Immun 67(12):6424-6433

Galen JE, Zhao L, Chinchilla M, Wang JY, Pasetti MF, Green J et al (2004) Adaptation of the endogenous Salmonella enterica serovar Typhi clyA-encoded hemolysin for antigen export enhances the immunogenicity of anthrax protective antigen domain 4 expressed by the attenuated live-vector vaccine strain CVD 908-htrA. Infect Immun 72(12):7096-7106. https://doi. org/10.1128/iai.72.12.7096

Galen JE, Pasetti MF, Tennant S, Ruiz-Olvera P, Sztein MB, Levine MM (2009) Salmonella enterica serovar Typhi live vector vaccines finally come of age. Immunol Cell Biol 87(5):400 412. https://doi.org/10.1038/icb.2009.31

Galen JE, Wang JY, Chinchilla M, Vindurampulle C, Vogel JE, Levy H et al (2010) A new generation of stable, nonantibiotic, low-copy-number plasmids improves immune responses to foreign antigens Salmonella enterica serovar typhi live vectors. Infect Immun 78(1):337-347. https://doi.org/10.1128/iai.00916-09 
Galen JE, Wang JY, Carrasco JA, Lloyd SA, Mellado-Sanchez G, Diaz-McNair J et al (2015) A bivalent typhoid live vector vaccine expressing both chromosome- and plasmid-encoded Yersinia pestis antigens fully protects against murine lethal pulmonary plague infection. Infect Immun 83(1):161-172. https://doi.org/10.1128/iai.02443-14

Gentschev I, Mollenkopf H, Sokolovic Z, Hess J, Kaufmann SH, Goebel W (1996) Development of antigen-delivery systems, based on the Escherichia coli hemolysin secretion pathway. Gene 179(1):133-140

Girón JA, Xu JG, González CR, Hone D, Kaper JB, Levine MM (1995) Simultaneous expression of CFA/I and CS3 colonization factor antigens of enterotoxigenic Escherichia coli by $\Delta$ aroC, $\Delta$ aroD Salmonella typhi vaccine strain CVD 908. Vaccine 13(10):939-946. https://doi. org/10.1016/0264-410x(95)00003-j

González CR, Noriega FR, Huerta S, Santiago A, Vega M, Paniagua J et al (1998) Immunogenicity of a Salmonella typhi CVD 908 candidate vaccine strain expressing the major surface protein gp63 of Leishmania mexicana mexicana. Vaccine 16(9-10):1043-1052. https://doi. org/10.1016/s0264-410x(97)00267-3

Goulart C, Rodriguez D, Kanno AI, Converso TR, Lu YJ, Malley R, et al (2017) A combination of recombinant BCG expressing pneumococcal proteins induces cellular and humoral immune responses and protects against pneumococcal colonization and sepsis. Clin Vaccine Immunol CVI.00133-00117. https://doi.org/10.1128/cvi.00133-17.

Grode L, Kursar M, Fensterle J, Kaufmann SHE, Hess J (2002) Cell-mediated immunity induced by recombinant Mycobacterium bovis Bacille Calmette-Guérin strains against an intracellular bacterial pathogen: importance of antigen secretion or membrane-targeted antigen display as lipoprotein for vaccine efficacy. J Immunol 168(4):1869-1876. https://doi.org/10.4049/ jimmunol.168.4.1869

Gu Q, Song D, Zhu M (2009) Oral vaccination of mice against Helicobacter pylori with recombinant Lactococcus lactis expressing urease subunit B. FEMS Immunol Med Microbiol 56(3):197-203. https://doi.org/10.1111/j.1574-695X.2009.00566.x

Hajam IA, Lee JH (2017) An influenza HA and M2e based vaccine delivered by a novel attenuated Salmonella mutant protects mice against homologous H1N1 infection. Front Microbiol 8:1-13. https://doi.org/10.3389/fmicb.2017.00872

Hart BE, Asrican R, Lim SY, Sixsmith JD, Lukose R, Souther SJR et al (2015) Stable expression of lentiviral antigens by quality-controlled recombinant mycobacterium bovis BCG vectors. Clin Vaccine Immunol 22(7):726-741. https://doi.org/10.1128/cvi.00075-15

Hatano S, Tamura T, Umemura M, Matsuzaki G, Ohara N, Yoshikai Y (2016) Recombinant Mycobacterium bovis bacillus Calmette-Guérin expressing Ag85B-IL-7 fusion protein enhances IL-17A-producing innate $\gamma \delta \mathrm{T}$ cells. Vaccine 34(22):2490-2495. https://doi. org/10.1016/j.vaccine.2016.03.096

Hindle Z, Chatfield SN, Phillimore J, Bentley M, Johnson J, Cosgrove CA et al (2002) Characterization of Salmonella enterica derivatives harboring defined aroC and Salmonella pathogenicity island 2 type III secretion system (ssaV) mutations by immunization of healthy volunteers. Infect Immun 70(7):3457-3467. https://doi.org/10.1128/iai.70.7.3457-3467.2002

Hoiseth SK, Stocker BAD (1981) Aromatic-dependent Salmonella typhimurium are non-virulent and effective as live vaccines. Nature 291(5812):238-239. https://doi.org/10.1038/291238a0

Igwe EI, Geginat G, Rüssmann H (2002) Concomitant cytosolic delivery of two immunodominant Listerial antigens by Salmonella enterica serovar typhimurium confers superior protection against murine listeriosis. Infect Immun 70(12):7114-7119. https://doi.org/10.1128/ iai.70.12.7114-7119.2002

Im E-J, Borducchi EN, Provine NM, McNally AG, Li S, Frankel FR et al (2013) An attenuated Listeria monocytogenes vector primes more potent simian immunodeficiency virusspecific mucosal immunity than DNA vaccines in mice. J Virol 87(8):4751-4755. https://doi. org/10.1128/jvi.03085-12 
Isoda R, Simanski SP, Pathangey L, Stone AES, Brown TA (2007) Expression of a Porphyromonas gingivalis hemagglutinin on the surface of a Salmonella vaccine vector. Vaccine 25(1):117126. https://doi.org/10.1016/j.vaccine.2006.06.085

Jenikova G, Hruz P, Andersson MK, Tejman-Yarden N, Ferreira PCD, Andersen YS et al (2011) ??1-giardin based live heterologous vaccine protects against Giardia lamblia infection in a murine model. Vaccine 29(51):9529-9537. https://doi.org/10.1016/j.vaccine.2011.09.126

Jennison AV, Verma NK (2004) Shigella flexneri infection: pathogenesis and vaccine development. FEMS Microbiol Rev 28(1):43-58. https://doi.org/10.1016/j.femsre.2003.07.002

Jia Y, Yin Y, Duan F, Fu H, Hu M, Gao Y et al (2012) Prophylactic and therapeutic efficacy of an attenuated Listeria monocytogenes-based vaccine delivering HPV16 E7 in a mouse model. Int J Mol Med 30(6):1335-1342. https://doi.org/10.3892/ijmm.2012.1136

Jiang S, Rasmussen RA, Nolan KM, Frankel FR, Lieberman J, McClure HM et al (2007) Live attenuated Listeria monocytogenes expressing HIV Gag: immunogenicity in rhesus monkeys. Vaccine 25(42):7470-7479. https://doi.org/10.1016/j.vaccine.2007.08.013

Joan SSX, Pui-Fong J, Song AAL, Chang LY, Yusoff K, AbuBakar S et al (2016) Oral vaccine of Lactococcus lactis harbouring pandemic H1N1 2009 haemagglutinin1 and nisP anchor fusion protein elevates anti-HA1 sIgA levels in mice. Biotechnol Lett 38(5):793-799. https://doi. org/10.1007/s10529-016-2034-2

Johnson PV, Blair BM, Zeller S, Kotton CN, Hohmann EL (2011) Attenuated Listeria monocytogenes vaccine vectors expressing influenza A nucleoprotein: preclinical evaluation and oral inoculation of volunteers. Microbiol Immunol 55(5):304-317. https://doi. org/10.1111/j.1348-0421.2011.00322.x

Kang HY, Srinivasan J, Curtiss R (2002) Immune responses to recombinant pneumococcal PspA antigen delivered by live attenuated Salmonella enterica serovar typhimurium vaccine. Infect Immun 70(4):1739-1749. https://doi.org/10.1128/iai.70.4.1739

Karpenko LI, Nekrasova NA, Ilyichev AA, Lebedev LR, Ignatyev GM, Agafonov AP et al (2004) Comparative analysis using a mouse model of the immunogenicity of artificial VLP and attenuated Salmonella strain carrying a DNA-vaccine encoding HIV-1 polyepitope CTL-immunogen. Vaccine 22(13-14):1692-1699. https://doi.org/10.1016/j.vaccine.2003.09.050

Kasinskas RW, Forbes NS (2007) Salmonella typhimurium lacking ribose chemoreceptors localize in tumor quiescence and induce apoptosis. Cancer Res. https://doi.org/10.1158/0008-5472. can-06-2618.

Khan SA, Stratford R, Wu T, McKelvie N, Bellaby T, Hindle Z et al (2003) Salmonella typhi and S. typhimurium derivatives harbouring deletions in aromatic biosynthesis and Salmonella Pathogenicity Island-2 (SPI-2) genes as vaccines and vectors. Vaccine 21(5-6):538-548. https://doi.org/10.1016/s0264-410x(02)00410-3

Kim SJ, Jun DY, Yang CH, Kim YH (2006) Expression of Helicobacter pylori cag12 gene in Lactococcus lactis MG1363 and its oral administration to induce systemic antiCag12 immune response in mice. Appl Microbiol Biotechnol 72(3):462-470. https://doi. org/10.1007/11679363_58

Kim SJ, Lee JY, Jun DY, Song JY, Lee WK, Cho MJ et al (2009) Oral administration of Lactococcus lactis expressing Helicobacter pylori Cag7-ct383 protein induces systemic antiCag7 immune response in mice. FEMS Immunol Med Microbiol 57(3):257-268. https://doi. org/10.1111/j.1574-695X.2009.00605.x

Kim WK, Moon JY, Kim S, Hur J (2016) Comparison between immunization routes of live attenuated Salmonella typhimurium strains expressing BCSP31, Omp3b, and SOD of Brucella abortus in murine model. Front Microbiol 7:1-8. https://doi.org/10.3389/fmicb.2016.00550

Kobierecka PA, Olech B, Ksiazek M, Derlatka K, Adamska I, Majewski PM et al (2016) Cell wall anchoring of the Campylobacter antigens to Lactococcus lactis. Front Microbiol 7:1-18. https://doi.org/10.3389/fmicb.2016.00165

Kong Q, Liu Q, Roland KL, Curtiss R (2009) Regulated delayed expression of rfaH in an attenuated Salmonella enterica serovar typhimurium a vaccine enhances immunogenicity of outer 
membrane proteins and a heterologous antigen. Infect Immun 77(12):5572-5582. https://doi. org/10.1128/iai.00831-09

Kong Q, Liu Q, Jansen AM, Curtiss R (2010) Regulated delayed expression of rfc enhances the immunogenicity and protective efficacy of a heterologous antigen delivered by live attenuated Salmonella enterica vaccines. Vaccine 28(37):6094-6103. https://doi.org/10.1016/j. vaccine.2010.06.074

Kong Q, Six DA, Roland KL, Liu Q, Gu L, Reynolds CM et al (2011) Salmonella synthesizing 1-monophosphorylated Lipopolysaccharide exhibits low endotoxic activity while retaining its immunogenicity. J Immunol 187(1):412-423. https://doi.org/10.4049/jimmunol.1100339

Kong W, Brovold M, Koeneman BA, Clark-Curtiss J, Curtiss R (2012) Turning self-destructing Salmonella into a universal DNA vaccine delivery platform. Proc Natl Acad Sci U S A 109(47):19414-19419. https://doi.org/10.1073/pnas.1217554109

Koprowski H, Levine MM, Anderson RJ, Losonsky G, Pizza M, Barry EM (2000) Attenuated shigella flexneri 2a vaccine strain CVD 1204 expressing colonization factor antigen I and mutant heat-labile enterotoxin of enterotoxigenic escherichia coli. Infect Immun 68(9):4884-4892. https://doi.org/10.1128/iai.68.9.4884-4892.2000

Kotton CN, Lankowski AJ, Scott N, Sisul D, Chen LM, Raschke K et al (2006) Safety and immunogenicity of attenuated Salmonella enterica serovar Typhimurium delivering an HIV-1 Gag antigen via the Salmonella Type III secretion system. Vaccine 24(37-39):6216-6224. https:// doi.org/10.1016/j.vaccine.2006.05.094

Kramer U, Rizos K, Apfel H, Ingo B, Lattemann CT, Autenrieth IB (2003) Autodisplay: development of an efficacious system for surface display of antigenic determinants in Salmonella vaccine strains. Infect Immun 71(4):1944-1952. https://doi.org/10.1128/iai.71.4.1944

Lakhashe SK, Velu V, Sciaranghella G, Siddappa NB, Dipasquale JM, Hemashettar G et al (2011) Prime-boost vaccination with heterologous live vectors encoding SIV gag and multimeric HIV-1 gp160 protein: efficacy against repeated mucosal R5 clade C SHIV challenges. Vaccine 29(34):5611-5622. https://doi.org/10.1016/j.vaccine.2011.06.017

Lalsiamthara J, Lee JH (2017) Brucella lipopolysaccharide reinforced Salmonella delivering Brucella immunogens protects mice against virulent challenge. Vet Microbiol 205:84-91. https://doi.org/10.1016/j.vetmic.2017.05.012

Lee C-H (2012) Engineering bacteria toward tumor targeting for cancer treatment: current state and perspectives. Appl Microbiol Biotechnol 93(2):517-523. https://doi.org/10.1007/ s00253-011-3695-3

Li L, Hu X, Wu Z, Xiong S, Zhou Z, Wang X et al (2009) Immunogenicity of self-adjuvanticity oral vaccine candidate based on use of Bacillus subtilis spore displaying Schistosoma japonicum 26 KDa GST protein. Parasitol Res 105(6):1643-1651. https://doi.org/10.1007/ s00436-009-1606-7

Li X, Xing Y, Guo L, Lv X, Song H, Xi T (2014) Oral immunization with recombinant Lactococcus lactis delivering a multi-epitope antigen CTB-UE attenuates Helicobacter pylori infection in mice. Pathog Dis 72(1):78-86. https://doi.org/10.1111/2049-632x.12173

Li Q-H, Jin G, Wang J-Y, Li H-N, Liu H, Chang X-Y et al (2016) Live attenuated Salmonella displaying HIV-1 10E8 epitope on fimbriae: systemic and mucosal immune responses in BALB/c mice by mucosal administration. Sci Rep 6(July):29556-29556. https://doi.org/10.1038/ srep29556

Liang ZZ, Sherrid AM, Wallecha A, Kollmann TR (2014) Listeria monocytogenes: a promising vehicle for neonatal vaccination. Hum Vaccin Immunother 10(4):1036-1046. https://doi. org/10.4161/hv.27999

Lin IYC, Van TTH, Smooker PM (2015) Live-attenuated bacterial vectors: tools for vaccine and therapeutic agent delivery. Vaccine 3(4):940-972

Liu D-s, Hu S-j, Zhou N-j, Xie Y, Cao J (2011) Construction and characterization of recombinant attenuated Salmonella typhimurium expressing the babA2/ureI fusion gene of Helicobacter pylori. Clin Res Hepatol Gastroenterol 35(10):655-660. https://doi.org/10.1016/j. clinre.2011.06.007 
Loessner H, Endmann A, Leschner S, Westphal K, Rohde M, Miloud T et al (2007) Remote control of tumour-targeted Salmonella enterica serovar Typhimurium by the use of 1-arabinose as inducer of bacterial gene expression in vivo. Cell Microbiol 9(6):1529-1537. https://doi. org/10.1111/j.1462-5822.2007.00890.x

Luo F, Feng Y, Liu M, Li P, Pan Q, Jeza VT et al (2007) Type IVB pilus operon promoter controlling expression of the severe acute respiratory syndrome-associated coronavirus nucleocapsid gene in Salmonella enterica serovar Typhi elicits full immune response by intranasal vaccination. Clin Vaccine Immunol 14(8):990-997. https://doi.org/10.1128/cvi.00076-07

Luria-Perez R, Cedillo-Barron L, Santos-Argumedo L, Ortiz-Navarrete VF, Ocaña-Mondragon A, Gonzalez-Bonilla CR (2007) A fusogenic peptide expressed on the surface of Salmonella enterica elicits CTL responses to a dengue virus epitope. Vaccine 25(27):5071-5085. https:// doi.org/10.1016/j.vaccine.2007.03.047

Mahant A, Saubi N, Eto Y, Guitart N, Gatell JM, Hanke T et al (2017) Preclinical development of BCG.HIVA2auxo.int, harboring an integrative expression vector, for a HIV-TB Pediatric vaccine. Enhancement of stability and specific HIV-1 T-cell immunity. Hum Vaccin Immunother 5515:1-13. https://doi.org/10.1080/21645515.2017.1316911

Mann BJ, Burkholder BV, Lockhart LA (1997) Protection in a gerbil model of amebiasis by oral immunization with Salmonella expressing the galactose/N-acetyl D-galactosamine inhibitable lectin of Entamoeba histolytica. Vaccine 15(6-7):659-663. https://doi.org/10.1016/ s0264-410x(96)00236-8

Mannam P, Jones KF, Geller BL (2004) Mucosal vaccine made from live, recombinant Lactococcus lactis protects mice against pharyngeal infection with Streptococcus pyogenes. Infect Immun 72(6):3444-3450. https://doi.org/10.1128/iai.72.6.3444-3450.2004

Matos MN, Cazorla SI, Bivona AE, Morales C, Guzman CA, Malchiodi EL (2014) Tc52 aminoterminal-domain DNA carried by attenuated Salmonella enterica serovar typhimurium induces protection against a trypanosoma cruzi lethal challenge. Infect Immun 82(10):4265-4275. https://doi.org/10.1128/iai.02190-14

Maurelli AT, Sansonetti PJ (1988) Genetic determinants of Shigella pathogenicity. Annu Rev Microbiol 42:127-150. https://doi.org/10.1146/annurev.mi.42.100188.001015

McLaughlin HP, Bahey-El-Din M, Casey PG, Hill C, Gahan CGM (2013) A mutant in the Listeria monocytogenes furregulated virulence locus (frvA) induces cellular immunity and confers protection against listeriosis in mice. J Med Microbiol 62(PART 2):185-190. https://doi. org/10.1099/jmm.0.049114-0

Mei Y, Zhao L, Liu Y, Gong H, Song Y, Lei L et al (2017) Combining DNA vaccine and AIDA-1 in attenuated Salmonella activates tumor-specific CD4 + and CD8 + T-cell responses. Cancer Immunol Res 5(6):503-514. https://doi.org/10.1158/2326-6066.cir-16-0240-t

Mellouk N, Enninga J (2016) Cytosolic access of intracellular bacterial pathogens: the Shigella paradigm. Front Cell Infect Microbiol 6:35. https://doi.org/10.3389/fcimb.2016.00035

Mignon C, Sodoyer R, Werle B (2015) Antibiotic-free selection in biotherapeutics: now and forever. Pathogens 4(2):157-181. https://doi.org/10.3390/pathogens4020157

Miki K, Nagata T, Tanaka T, Kim YH, Uchijima M, Ohara N et al (2004) Induction of protective cellular immunity against Mycobacterium tuberculosis by recombinant attenuated selfdestructing Listeria monocytogenes strains harboring eukaryotic expression plasmids for antigen 85 complex and MPB/MPT51. Infect Immun 72(4):2014-2021

Moliva JI, Turner J, Torrelles JB (2017) Immune responses to Bacillus Calmette-Guerin vaccination: why do they fail to protect against mycobacterium tuberculosis? Front Immunol 8:407. https://doi.org/10.3389/fimmu.2017.00407

Nascimento IP, Dias WO, Quintilio W, Christ AP, Moraes JF, Vancetto MDC et al (2008) Neonatal immunization with a single dose of recombinant BCG expressing subunit S1 from pertussis toxin induces complete protection against Bordetella pertussis intracerebral challenge. Microbes Infect 10(2):198-202. https://doi.org/10.1016/j.micinf.2007.10.010

Nascimento IP, Dias WO, Quintilio W, Hsu T, Jacobs WR, Leite LCC (2009) Construction of an unmarked recombinant BCG expressing a pertussis antigen by auxotrophic complementa- 
tion: protection against Bordetella pertussis challenge in neonates. Vaccine 27(52):7346-7351. https://doi.org/10.1016/j.vaccine.2009.09.043

Noriega FR, Losonsky G, Lauderbaugh C, Liao FM, Wang JY, Levine MM (1996) Engineered deltaguaB-A deltavirG Shigella flexneri 2a strain CVD 1205: construction, safety, immunogenicity, and potential efficacy as a mucosal vaccine. Infect Immun 64(8):3055-3061

Orr N, Galen JE, Levine MM (2001) Novel use of anaerobically induced promoter, dmsA, for controlled expression of fragment $\mathrm{C}$ of tetanus toxin in live attenuated Salmonella enterica serovar Typhi strain CVD 908-htrA. Vaccine 19(13-14):1694-1700. https://doi.org/10.1016/ s0264-410x(00)00400-x

Pasetti MF, Anderson RJ, Noriega FR, Levine MM, Sztein MB (1999) Attenuated deltaguaBA Salmonella typhi vaccine strain CVD 915 as a live vector utilizing prokaryotic or eukaryotic expression systems to deliver foreign antigens and elicit immune responses. Clin Immunol (Orlando, Fla) 92(1):76-89. https://doi.org/10.1006/clim.1999.4733

Pasetti MF, Pickett TE, Levine MM, Sztein MB (2000) A comparison of immunogenicity and in vivo distribution of Salmonella enterica serovar Typhi and Typhimurium live vector vaccines delivered by mucosal routes in the murine model. Vaccine 18(28):3208-3213. https://doi. org/10.1016/s0264-410x(00)00142-0

Pasetti MF, Salerno-Gonçalves R, Sztein MB (2002) Salmonella enterica serovar Typhi live vector vaccines delivered intranasally elicit regional and systemic specific CD8+ major histocompatibility class I-restricted cytotoxic T lymphocytes. Infect Immun 70(8):4009-4018. https://doi. org/10.1128/iai.70.8.4009-4018.2002

Pasetti MF, Simon JK, Sztein MB, Levine MM (2011) Immunology of gut mucosal vaccines. Immunol Rev 239(1):125-148. https://doi.org/10.1111/j.1600-065X.2010.00970.x

Pathangey L, Kohler JJ, Isoda R, Brown TA (2009) Effect of expression level on immune responses to recombinant oral Salmonella enterica serovar Typhimurium vaccines. Vaccine 27(20):27072711. https://doi.org/10.1016/j.vaccine.2009.02.072

Pei Z, Jiang X, Yang Z, Ren X, Gong H, Reeves M et al (2015) Oral delivery of a novel attenuated salmonella vaccine expressing influenza a virus proteins protects mice against $\mathrm{H} 5 \mathrm{~N} 1$ and H1N1 viral infection. PLoS ONE 10(6):1-20. https://doi.org/10.1371/journal.pone.0129276

Peters C, Domann E, Darbouche A, Chakraborty T, Mielke MEA (2003) Tailoring host immune responses to Listeria by manipulation of virulence genes - the interface between innate and acquired immunity. FEMS Immunol Med Microbiol 35(3):243-253. https://doi.org/10.1016/ s0928-8244(02)00469-8

Pham OH, McSorley SJ (2015) Protective host immune responses to Salmonella infection. Future Microbiol 10(1):101-110. https://doi.org/10.2217/fmb.14.98

Pilgrim S, Stritzker J, Schoen C, Kolb-Mäurer A, Geginat G, Loessner MJ et al (2003) Bactofection of mammalian cells by Listeria monocytogenes: improvement and mechanism of DNA delivery. Gene Ther 10(24):2036-2045. https://doi.org/10.1038/sj.gt.3302105

Ramirez K, Capozzo AVE, Lloyd SA, Sztein MB, Nataro JP, Pasetti MF (2009) Mucosally delivered Salmonella typhi expressing the Yersinia pestis F1 antigen elicits mucosal and systemic immunity early in life and primes the neonatal immune system for a vigorous anamnestic response to parenteral F1 boost. J Immunol (Baltimore, Md: 1950) 182(2):1211-1222 182/2/1211 [pii]

Ranallo RT, Fonseka CP, Cassels F, Srinivasan J, Venkatesan MM (2005) Construction and characterization of bivalent Shigella flexneri 2a vaccine strains SC608(pCFAI) and SC608(pCFAI/ LTB) that express antigens from enterotoxigenic Escherichia coli. Infect Immun 73(1):258267. https://doi.org/10.1128/iai.73.1.258-267.2005

Raupach B, Kaufmann SHE (2001) Bacterial virulence, proinflammatory cytokines and host immunity: how to choose the appropriate Salmonella vaccine strain? Microbes Infect 3(1415):1261-1269. https://doi.org/10.1016/s1286-4579(01)01486-1

Rayevskaya MV, Frankel FR (2001) Systemic immunity and mucosal immunity are induced against human immunodeficiency virus Gag protein in mice by a new hyperattenuated strain of Listeria monocytogenes. J Virol 75(6):2786-2791. https://doi.org/10.1128/jvi.75.6.2786-2791.2001 
Rayevskaya M, Kushnir N, Frankel FR (2002) Safety and immunogenicity in neonatal mice of a hyperattenuated Listeria vaccine directed against human immunodeficiency virus. J Virol 76(2):918-922. https://doi.org/10.1128/jvi.76.2.918-922.2002

Rezende CAF, De Moraes MTB, Matos DCDS, McIntoch D, Armoa GRG (2005) Humoral response and genetic stability of recombinant BCG expressing hepatitis B surface antigens. J Virol Methods 125(1):1-9. https://doi.org/10.1016/j.jviromet.2004.11.026

Roberts M, Chatfield S, Pickard D, Li J, Bacon A (2000) Comparison of abilities of Salmonella enterica serovar Typhimurium aroA aroD and aroA htrA mutants to act as live vectors. Infect Immun 68(10):6041-6043. https://doi.org/10.1128/iai.68.10.6041-6043.2000

Roche JK, Rojo AL, Costa LB, Smeltz R, Manque P, Woehlbier U et al (2013) Intranasal vaccination in mice with an attenuated Salmonella enterica Serovar 908htr A expressing Cp15 of Cryptosporidium: impact of malnutrition with preservation of cytokine secretion. Vaccine 31(6):912-918. https://doi.org/10.1016/j.vaccine.2012.12.007

Rojas RLG, Gomes PADP, Bentancor LV, Sbrogio-Almeida ME, Costa SOP, Massis LM et al (2010) Salmonella enterica serovar typhimurium vaccine strains expressing a nontoxic shigalike toxin 2 derivative induce partial protective immunity to the toxin expressed by enterohemorrhagic escherichia coli. Clin Vaccine Immunol 17(4):529-536. https://doi.org/10.1128/ cvi.00495-09

Ryan ET, Butterton JR, Smith RN, Carroll PA, Crean TI, Calderwood SB (1997) Protective immunity against Clostridium difficile toxin $\mathrm{A}$ induced by oral immunization with a live, attenuated Vibrio cholerae vector strain. Infect Immun 65(7):2941-2949

Ryan ET, Cream TI, John M, Butterton JR, Clements JD, Calderwood SB (1999) In vivo expression and immunoadjuvancy of a mutant of heat-labile enterotoxin of Escherichia coli in vaccine and vector strains of Vibrio cholerae. Infect Immun 67(4):1694-1701

Ryan ET, Crean TI, Kochi SK, John M, Luciano AA, Killeen KP et al (2000) Development of a ??glnA balanced lethal plasmid system for expression of heterologous antigens by attenuated vaccine vector strains of Vibrio cholerae. Infect Immun 68(1):221-226. https://doi.org/10.1128/ IAI.68.1.221-226.2000.Updated

Saklani-Jusforgues H, Fontan E, Soussi N, Milon G, Goossens PL (2003) Enteral immunization with attenuated recombinant Listeria monocytogenes as a live vaccine vector: organ-dependent dynamics of CD4 T lymphocytes reactive to a Leishmania major tracer epitope. Infect Immun 71(3):1083-1090. https://doi.org/10.1128/iai.71.3.1083-1090.2003

Schoen C, Stritzker J, Goebel W, Pilgrim S (2004) Bacteria as DNA vaccine carriers for genetic immunization. Int $\mathrm{J}$ Med Microbiol 294(5):319-335. https://doi.org/10.1016/j. ijmm.2004.03.001

Sciaranghella G, Lakhashe SK, Ayash-Rashkovsky M, Mirshahidi S, Siddappa NB, Novembre FJ et al (2011) A live attenuated Listeria monocytogenes vaccine vector expressing SIV Gag is safe and immunogenic in macaques and can be administered repeatedly. Vaccine 29(3):476486. https://doi.org/10.1016/j.vaccine.2010.10.072

Sevil Domènech VE, Panthel K, Winter SE, Rüssmann H (2008) Heterologous prime-boost immunizations with different Salmonella serovars for enhanced antigen-specific CD8 T-cell induction. Vaccine 26(15):1879-1886. https://doi.org/10.1016/j.vaccine.2008.01.044

Shahabi V, Seavey MM, Maciag PC, Rivera S, Wallecha A (2011) Development of a live and highly attenuated Listeria monocytogenes-based vaccine for the treatment of Her2/neuoverexpressing cancers in human. Cancer Gene Ther 18(1):53-62. https://doi.org/10.1038/ cgt. 2010.48

Shi H, Santander J, Brenneman KE, Wanda SY, Wang S, Senechal P et al (2010) Live recombinant Salmonella typhi vaccines constructed to investigate the role of rpoS in eliciting immunity to a heterologous antigen. PLoS ONE 5(6). https://doi.org/10.1371/journal.pone.0011142

Sibley L, Reljic R, Radford DS, Huang JM, Hong HA, Cranenburgh RM et al (2014) Recombinant Bacillus subtilis spores expressing MPT64 evaluated as a vaccine against tuberculosis in the murine model. FEMS Microbiol Lett 358(2):170-179. https://doi. org/10.1111/1574-6968.12525 
Sizemore DR, Warner EA, Lawrence JA, Thomas LJ, Roland KL, Killeen KP (2012) Construction and screening of attenuated ??phoP/Q Salmonella typhimurium vectored plague vaccine candidates. Hum Vaccin Immunother 8(3):371-383. https://doi.org/10.4161/hv.8.3.18670

Soussi N, Saklani-Jusforgues H, Colle JH, Milon G, Glaichenhaus N, Goossens PL (2002) Effect of intragastric and intraperitoneal immunisation with attenuated and wild-type LACKexpressing Listeria monocytogenes on control of murine Leishmania major infection. Vaccine 20(21-22):2702-2712. https://doi.org/10.1016/s0264-410x(02)00198-6

Spreng S, Gentschev I, Goebel W, Weidinger G, Ter Meulen V, Niewiesk S (2000) Salmonella vaccines secreting measles virus epitopes induce protective immune responses against measles virus encephalitis. Microbes Infect 2(14):1687-1692. https://doi.org/10.1016/ s1286-4579(00)01325-3

Starks H, Bruhn KW, Shen H, Barry RA, Dubensky TW, Brockstedt D et al (2004) Listeria monocytogenes as a vaccine vector: virulence attenuation or existing antivector immunity does not diminish therapeutic efficacy. J Immunol 173(1):420-427. https://doi.org/10.4049/ jimmunol.173.1.420

Stasilojc M, Hinc K, Peszynska-Sularz G, Obuchowski M, Iwanicki A (2015) Recombinant Bacillus subtilis spores elicit Th1/Th17-polarized immune response in a Murine model of Helicobacter pylori vaccination. Mol Biotechnol 57(8):685-691. https://doi.org/10.1007/ s12033-015-9859-0

Stevens R, Howard KE, Nordone S, Burkhard M, Dean GA (2004) Oral immunization with recombinant Listeria monocytogenes controls virus load after vaginal challenge with feline immunodeficiency virus. J Virol 78(15):8210-8218. https://doi.org/10.1128/jvi.78.15.8210-8218.2004

Strain SL-v, Altboum Z, Levine MM, Galen JE, Barry EM (2003) Genetic characterization and immunogenicity of coli surface antigen 4 from enterotoxigenic Escherichia coli when it is expressed in a Shigella live-vector strain. Infect Immun 71(3):1352-1360. https://doi. org/10.1128/iai.71.3.1352

Strugnell R, Dougan G, Chatfield S, Charles I, Fairweather N, Tite J et al (1992) Characterization of a Salmonella typhimurium aro vaccine strain expressing the P.69 antigen of Bordetella pertussis. Infect Immun 60(10):3994-4002

Sun W, Olinzock J, Wang S, Sanapala S, Curtiss R (2014) Evaluation of YadC protein delivered by live attenuated Salmonella as a vaccine against plague. Pathog Dis 70(2):119-131. https://doi. org/10.1111/2049-632x.12076

Szatraj K, Szczepankowska AK, Chmielewska-Jeznach M (2017) Lactic acid bacteria - promising vaccine vectors: possibilities, limitations, doubts. J Appl Microbiol 123(2):325-339. https:// doi.org/10.1111/jam.13446

Tacket C, Hone DM, Curtiss ROY, Kelly SM, Losonsky G, Guers L et al (1992) Comparison of the safety and immunogenicity of DaroC DaroD and \& cya Acrp Salmonella typhi strains in adult volunteers. Infect Immun 3:536-541

Tacket CO, Kelly SM, Schödel F, Losonsky G, Nataro JP, Edelman R et al (1997) Safety and immunogenicity in humans of an attenuated Salmonella typhi vaccine vector strain expressing plasmid-encoded hepatitis B antigens stabilized by the Asd-balanced lethal vector system. Infect Immun 65(8):3381-3385

Tacket CO, Sztein MB, Wasserman SS, Losonsky G, Kotloff KL, Wyant TL et al (2000) Phase 2 clinical trial of attenuated Salmonella enterica serovar Typhi oral live vector vaccine CVD 908-htrAin U.S. volunteers. Infect Immun 68(3):1196-1201. https://doi.org/10.1128/ iai.68.3.1196-1201.2000

Tobias J, Lebens M, Wai SN, Holmgren J, Svennerholm AM (2017) Surface expression of Helicobacter pylori HpaA adhesion antigen on Vibrio cholerae, enhanced by co-expressed enterotoxigenic Escherichia coli fimbrial antigens. Microb Pathog 105:177-184. https://doi. org/10.1016/j.micpath.2017.02.021

Torres-Escobar A, Juárez-Rodríguez MD, Gunn BM, Branger CG, Tinge SA, Curtiss R (2010) Fine-tuning synthesis of yersinia pestis lcrv from runaway-like replication balanced-lethal plasmid in a salmonella enterica serovar typhimurium vaccine induces protection against a 
lethal y. pestis challenge in mice. Infect Immun 78(6):2529-2543. https://doi.org/10.1128/ iai.00005-10

Tvinnereim AR, Hamilton SE, Harty JT (2002) CD8 + -T-cell response to secreted and nonsecreted antigens delivered by recombinant Listeria monocytogenes during secondary infection. Infect Immun 70(1):153-162. https://doi.org/10.1128/iai.70.1.153

Venkataswamy MM, Ng TW, Kharkwal SS, Carreño LJ, Johnson AJ, Kunnath-Velayudhan S et al (2014) Improving Mycobacterium bovis bacillus calmette-Guèrin as a vaccine delivery vector for viral antigens by incorporation of glycolipid activators of NKT cells. PLoS ONE 9(9):e108383. https://doi.org/10.1371/journal.pone.0108383

Verch T, Pan Z-k, Paterson Y (2004) Listeria monocytogenes-based antibiotic resistance gene-free antigen delivery system applicable to other bacterial vectors and DNA vaccines. Infect Immun 72(11):6418-6425. https://doi.org/10.1128/iai.72.11.6418

Wallecha A, Maciag P, Rivera S, Paterson Y, Shahabi V (2009) Construction and characterization of an attenuated Listeria monocytogenes strain for clinical use in cancer immunotherapy. Clin Vaccine Immunol 16(1):96-103. https://doi.org/10.1128/cvi.00274-08

Wang JY, Pasetti MF, Noriega FR, Anderson RJ, Wasserman SS, James E et al (2001) Construction, genotypic and phenotypic characterization, and immunogenicity of attenuated $\Delta$ guaBA Salmonella enterica Serovar Typhi S. Infect Immun 69(8):4734-4741. https://doi.org/10.1128/ iai.69.8.4734

Wang Q1, Pan Q, Ma Y, Wang K, Sun P, Liu S et al (2009) An attenuated Salmonella-vectored vaccine elicits protective immunity against Mycobacterium tuberculosis. Vaccine 27(48):67126722. https://doi.org/10.1016/j.vaccine.2009.08.096

Wang S, Li Y, Scarpellini G, Kong W, Shi HY, Baek CH et al (2010) Salmonella vaccine vectors displaying delayed antigen synthesis in vivo to enhance immunogenicity. Infect Immun 78(9):3969-3980. https://doi.org/10.1128/iai.00444-10

Wang S, Li Y, Shi H, Sun W, Roland KL, Curtiss R (2011) Comparison of a regulated delayed antigen synthesis system with in vivo-inducible promoters for antigen delivery by live attenuated Salmonella vaccines. Infect Immun 79(2):937-949. https://doi.org/10.1128/iai.00445-10

Wang S, Kong Q, Curtiss R (2013) New technologies in developing recombinant attenuated Salmonella vaccine vectors. Microb Pathog 58:17-28. https://doi.org/10.1016/j. micpath.2012.10.006

Wyszyńska A, Raczko A, Lis M, Jagusztyn-Krynicka EK (2004) Oral immunization of chickens with avirulent Salmonella vaccine strain carrying C. jejuni 72Dz/92 cjaA gene elicits specific humoral immune response associated with protection against challenge with wild-type Campylobacter. Vaccine 22(11-12):1379-1389. https://doi.org/10.1016/j.vaccine.2003.11.001

Xin W, Li Y, Mo H, Roland KL, Curtiss R (2009) PspA family fusion proteins delivered by attenuated Salmonella enterica serovar typhimurium extend and enhance protection against Streptococcus pneumoniae. Infect Immun 77(10):4518-4528. https://doi.org/10.1128/ iai.00486-09

Xiong X, Jiao J, Gregory AE, Wang P, Bi Y, Wang X et al (2017) Identification of Coxiella burnetii CD8 + T-cell epitopes and delivery by attenuated Listeria monocytogenes as a vaccine vector in a C57BL/6 mouse model. J Infect Dis 215(10):1580-1589. https://doi.org/10.1093/infdis/ jiw470

Xu C, Li ZS, Du YD, Tu ZX, Gong YF, Jin J et al (2005) Construction of a recombinant attenuated Salmonella typhimurium DNA vaccine carrying Helicobacter pylori hpaA. World J Gastroenterol 11(1):114-117

Yang Y, Zhang Z, Yang J, Chen X, Cui S, Zhu X (2010) Oral vaccination with Ts87 DNA vaccine delivered by attenuated Salmonella typhimurium elicits a protective immune response against Trichinella spiralis larval challenge. Vaccine 28(15):2735-2742. https://doi.org/10.1016/j. vaccine.2010.01.026

Yang X-q, Zhao Y-g, Chen X-q, Jiang B, Sun D-y (2013) The protective effect of recombinant Lactococcus lactis oral vaccine on a Clostridium difficile-infected animal model. BMC Gastroenterol 13(1):117-117. https://doi.org/10.1186/1471-230x-13-117 
Yu J, Chen T, Xie Z, Liang P, Qu H, Shang M et al (2015) Oral delivery of Bacillus subtilis spore expressing enolase of Clonorchis sinensis in rat model: induce systemic and local mucosal immune responses and has no side effect on liver function. Parasitol Res 114(7):2499-2505. https://doi.org/10.1007/s00436-015-4449-4

Zamri HF, Shamsudin MN, Rahim RA, Neela V (2012) Oral vaccination with Lactococcus lactis expressing the Vibrio cholerae Wzm protein to enhance mucosal and systemic immunity. Vaccine 30(21):3231-3238. https://doi.org/10.1016/j.vaccine.2012.02.012

Zenewicz LA, Shen H (2007) Innate and adaptive immune responses to Listeria monocytogenes: a short overview. Microbes Infect 9(10):1208-1215. https://doi.org/10.1016/j. micinf.2007.05.008

Zhang Q, Ma Q, Li Q, Yao W, Wang C (2011) Enhanced protection against nasopharyngeal carriage of Streptococcus pneumoniae elicited by oral multiantigen DNA vaccines delivered in attenuated Salmonella typhimurium. Mol Biol Rep 38(2):1209-1217. https://doi.org/10.1007/ s11033-010-0219-7

Zhang D, Huang X, Zhang X, Cao S, Wen X, Wen Y et al (2016a) Construction of an oral vaccine for transmissible gastroenteritis virus based on the TGEV N gene expressed in an attenuated Salmonella typhimurium vector. J Virol Methods 227:6-13. https://doi.org/10.1016/j. jviromet.2015.08.011

Zhang R, Duan G, Shi Q, Chen S, Fan Q, Sun N et al (2016b) Construction of a recombinant Lactococcus lactis strain expressing a fusion protein of Omp22 and HpaA from Helicobacter pylori for oral vaccine development. Biotechnol Lett 38(11):1911-1916. https://doi. org/10.1007/s10529-016-2173-5

Zheng JP, Zhang ZS, Li SQ, Liu XX, Yuan SL, Wang P et al (2005) Construction of a novel Shigella live-vector strain co-expressing CS3 and LTB/STm of enterotoxigenic E.coli. World J Gastroenterol 11(22):3411-3418

Zheng Y-q, Naguib YW, Dong Y, Shi Y-c, Bou S, Cui Z (2015) Applications of bacillus CalmetteGuerin and recombinant bacillus Calmette-Guerin in vaccine development and tumor immunotherapy. Expert Rev Vaccines 14(9):1255-1275. https://doi.org/10.1586/14760584.2015.10 68124

Zhou Z, Gong S, Yang Y, Guan R, Zhou S, Yao S et al (2015) Expression of Helicobacter pylori urease B on the surface of Bacillus subtilis spores. J Med Microbiol 64(1):104-110. https://doi. org/10.1099/jmm.0.076430-0

Zhu C, Ruiz-Perez F, Yang Z, Mao Y, Hackethal VL, Greco KM et al (2006) Delivery of heterologous protein antigens via hemolysin or autotransporter systems by an attenuated ler mutant of rabbit enteropathogenic Escherichia coli. Vaccine 24(18):3821-3831. https://doi.org/10.1016/j. vaccine.2005.07.024 